\title{
A Review on the Antidiabetic Potential of Medicinal Plants
}

\section{Razan Bushnak}

Recherche et Développement des Médicaments et des Produits Naturels RDMPN, Faculty of Pharmacy, Lebanese University, Hadath, Lebanon

\section{Mohamad El Hajj}

Doctoral School of Science and Technology, Research Platform for Environmental Science (PRASE), Lebanese University, Hadath, Lebanon

\author{
Ali Jaber* \\ Recherche et Développement des Médicaments et des Produits Naturels RDMPN, Faculty of Pharmacy, Lebanese \\ University, Hadath, Lebanon \\ Email: ali.jaber.2@ul.edu.1b
}

\section{Article History}

Received: September 29, 2021

Revised: November 10, 2021

Accepted: November 15, 2021

Published: November 18, 2021

\begin{abstract}
Diabetes mellitus has long been seen as a substantial economic burden on patients, their families, and society. Impairment in blood sugar regulation has major health repercussions. Furthermore, untreated diabetes causes major chronic complications like blindness, renal failure, and heart failure, as well as an increase in associated mortality. New anti-diabetic medicines are being researched to help alleviate this issue. Conventional Anti-diabetic medications are beneficial, several synthetic drugs are available in the market to treat diabetes, but they are costly and come with inevitable adverse effects. Medicinal plants, on the other hand, may serve as an alternate source of anti-diabetic agents. According to the World Health Organization, $80 \%$ of the population in underdeveloped nations still relies on traditional medicines or folk medicines, which are largely made from plants, for disease prevention or treatment. For instance, antiproliferative, anti-viral, anti-inflammatory and anti-hyperglycemic effects. In order to find a natural anti-diabetic source that comes with less side effects, several studies have been conducted. The aim of this work is to review these studies and highlight the potential of plants when it comes to their anti-diabetic effect.
\end{abstract}

Keywords: Diabetes mellitus; Medicinal plants; Antidiabetic; Hypoglycemic; Antihyperglycemic.

\section{Introduction}

Medical plants have been used for medicinal purposes since ancient times, and they may even be considered the origin of modern medicine. Plant-derived compounds have been and continue to be a valuable source of compounds for pharmaceuticals $[1,2]$. Medicinal plants are a reservoir of biologically active compounds with therapeutic characteristics that have been documented and utilized for the treatment of a variety of diseases by various groups of people over time [3]. Civilizations have produced herbal medicine based on their local environment. Some authors even say that this passed-down knowledge is the source of medicine and pharmacy. Hundreds of higher plants are still cultivated today to extract important compounds in medicine and pharmacy all across the world. Plants are increasingly becoming acknowledged as promising drug discovery sources, with more than $30-50 \%$ of current pharmaceuticals derived directly from natural sources (plants, microorganisms, cells, etc.) or their molecules/compounds [4]. For instance, in sector of cancer studies, plants have contributed more than $60 \%$ of the anti-cancer drugs, directly or indirectly [4]. Therefore, this review briefly focuses on the pharmacological effects of some plants which have been widely studied and used in diabetic treatment.

\section{Various Biological Activities of Medicinal Plants}

Traditional medicines are an important part of alternative health care systems that are utilized by millions of people throughout the world. Plants are increasingly becoming acknowledged as promising drug discovery sources, with more than $80 \%$ of current pharmaceuticals derived directly from natural sources (plants, microorganisms, cells, etc.) or their molecules/compounds [5].

Drug discovery from plants nowadays requires a multidisciplinary approach that combines ethnobotanical, phytochemical, and biological techniques to provide us with new chemical compounds (lead molecules) for the development of drugs against a wide range of pharmacological targets [6]. For instance, the Annona crassiflora extract obtained from the seeds had a strong anti-proliferative impact. These extracts were high in phenolic acids, particularly caffeic acid, sinapic acid, ferulic acid, and flavonoid, and presented anticancer properties that could be related to their phenolic acid concentration [7].

Basilicum ocimum $L$. containing sesquiterpenoid, flavonoids, and triterpenoids like ursolic acid, agents knowing to be inhibitor of various viral infections of DNA and RNA viruses [8]. Ipomoea pescaprae leaf extracts were found to be effective in treating dermatitis caused by jellyfish stings and edema caused by ethyl phenylpropiolate in mice [9].

*Corresponding Author 
In another study, the phenolic molecules eugenol and its derivatives, which suppress the activity of the proinflammatory enzymes cyclooxygenase-2 (COX-2) and lipoxygenase (LOX), have been linked to Syzygium aromaticum's anti-inflammatory properties [10]. Plantamajoside, a hydroxycinnamic acid, in Plantago asiatica L. is a well-known polyphenolic molecule with anti-inflammatory properties, and ethanolic extracts of this plant suppressed the mRNA expression of pro-inflammatory mediators (IL-1, IL-6, iNOS, COX-2, and NF-B) in macrophages, inhibiting NO generation [11]. Another example is the lectins extracted from Canavalia brasiliensis seeds and Canavalia ensiformes seeds were found to have antidepressant efficacy through their interaction with serotoninergic (5-HT1A, 5-HT 2 receptors), noradrenergic (alpha 2 adrenoceptor), and dopaminergic (D 2 receptor) systems [12].

\section{Anti-diabetic Effect of Medicinal Plants}

Although synthetic oral hypoglycemic medications and insulin are the most common methods for treating diabetes, they do not totally reverse the disease's complications and, in addition, they have significant adverse effects [13]. Glucose-lowering medications commonly used might have effects on COVID-19 pathogenesis, and could have implications for the management of patients with diabetes mellitus and COVID-19 [14]. This is the driving factor behind the search for new anti-diabetic medications [15]. Despite significant progress in the treatment of diabetes with oral antidiabetic drugs during the last three decades, diabetic patient treatment outcomes are still far from ideal. The usage of those oral hypoglycemic medications has been linked to a number of disadvantages, including drug resistance (reduction of efficiency, side effects and toxicity. Sulfonylureas, for example, are known to lose their effectiveness in around $44 \%$ of patients after 6 years of treatment, whilst glucose-lowering medications are believed to be unable to control hyperlipidemia. The search for newer antidiabetic medications from natural sources continues due to many constraints associated with the utilization of existing synthetic antidiabetic agents [16].

Natural products, particularly those of plant origin, are the primary target for identifying viable lead candidates and will play a critical role in future drug developmental projects [17, 18]. Medicinal plants used to treat hypoglycemic or hyperglycemic conditions are of keen interest to the ethnobotanical community because they are known to contain valuable medicinal properties in various parts of the plant, and a number of plants have demonstrated varying degrees of hypoglycemic and anti-hyperglycemic activity. Plant-based preparations are the main essential component of all current medicines, especially in rural regions, due to their ease of availability, low cost, and minimal adverse effects [16]. Furthermore, many plants have a variety of bioactive compounds that are free of side effects and have potent pharmacological effects [19]. Traditional plant treatments or herbal formulations may hold the key to resolving diabetic issues in a natural way [20]. Furthermore, medicinal herbs are utilized to treat diabetes in developing countries, particularly to reduce the financial load of conventional drugs on the population [16].

Plants' anti-hyperglycemic properties are mainly related to their ability to improve the performance of pancreatic tissue, which is accomplished by elevating insulin secretions or limiting glucose absorption in the intestine [16, 21, 22]. The number of people living with diabetes is rising, creating concerns among medical professionals and the general population. Despite the availability of anti-diabetic medications on the market, medicinal herbs are often effective in the treatment of diabetes. Herbal treatments and plant components with low toxicity and no side effects are notable treatment options for diabetes around the world.

Nowadays, medicinal plants are used to treat diseases such as diabetes because they include phytoconstituents such as flavonoids, terpenoids, saponins, carotenoids, alkaloids, and glycosides, which may have anti-diabetic properties. Furthermore, the combined action of biologically active compounds (e.g., polyphenols, carotenoids, lignans, coumarins, glucosinolates, etc.) leads to the potential beneficial properties of each plant matrix, which can serve as a starting point for understanding their biological actions and beneficial activities [16].

Coumarins have hypoglycemic properties and decrease the activity of the enzyme aldose reductase as well as platelet aggregation, both of which are thought to be causes of diabetic problems [23]. This family of plant compounds includes coumarin fraxidin. Likewise, various alkaloids were found potentially effective against different diabetic models [24, 25]. Quinolizidine alkaloids, such as lupanines, sparteine and multiflorine, beside their role in lowering the blood glucose, they have been associated with insulinotropic effects on isolated pancreatic islets [26]. Other alkaloids such as berberine, boldine and sanguinarine were found to have potential anti-diabetic activity [24]. Moreover, studies show that polyphenols are able to grant anti-diabetic effects via different suggested mechanisms: increase insulin secretion, insulin sensitivity and insulin-dependent glucose uptake, inhibit glucose absorption in the intestine by sodium-dependent glucose transporter 1 (SGLT1), reduce hepatic glucose output, and influence the gut microbiome. 4-hydroxybenzoic acid, for example, has a hypoglycemic effect in normal rats by increasing serum insulin levels and liver glycogen levels [27, 28]. Some flavonoids stimulate insulin release from isolated Langerhans islets in a concentration-dependent way. Rutin, for example, is a flavonoid with hypoglycemic characteristics [29]. On the other hand, saponin's ability to lower increased plasma blood sugar levels makes it a good choice for diabetes mellitus treatment [30-32]. The hypoglycemic action of saponin come through different pathways, among them we cite : restoration of insulin response [33], improvement in insulin signaling [34], increase plasma insulin levels , and induction of insulin release from the pancreas [35], activation of glycogen synthesis [36], inhibition of gluconeogenesis [37], etc.. 


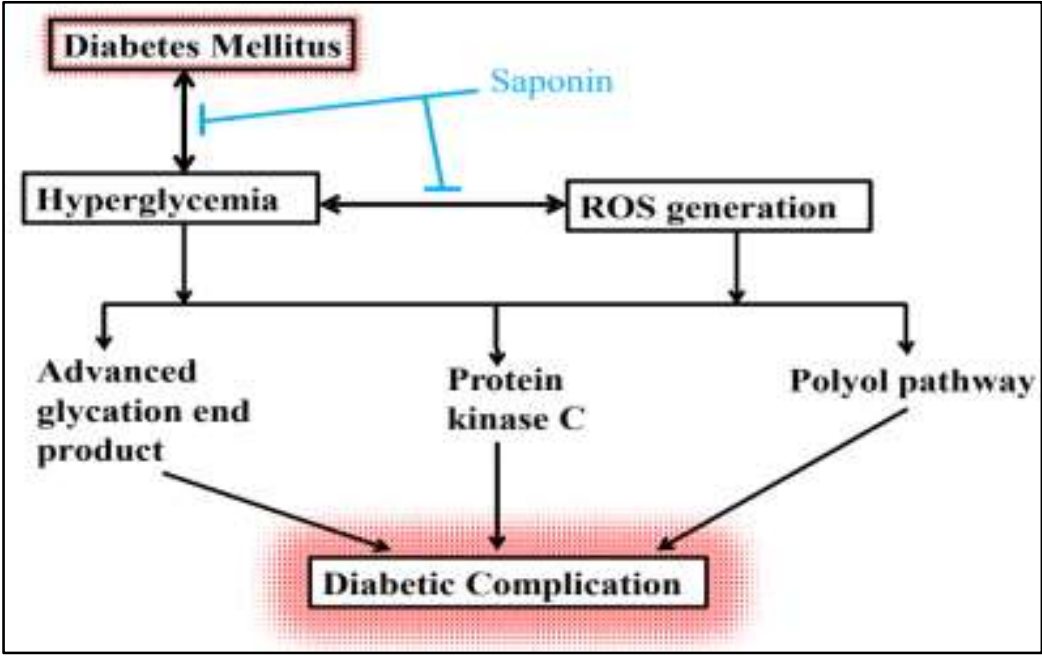

In this section, plant species will be organized in their suggested action mechanisms in antidiabetic potential. Although the mechanisms of action of the antidiabetic activity of certain plants are multiple and can be attributed to several actions, plants in this review have been classified according to the most probable mechanism. Among different actions of diabetes treatment, we cite the regeneration, protection and stimulation of the $\beta$-cells of islets of Langerhans to release more insulin, the enhancement of peripheral consumption of glucose, the inhibition of the intestinal absorption of glucose, and a sparing insulin effect.

Figure-2. Different possible mechanisms of plant for diabetes treatment

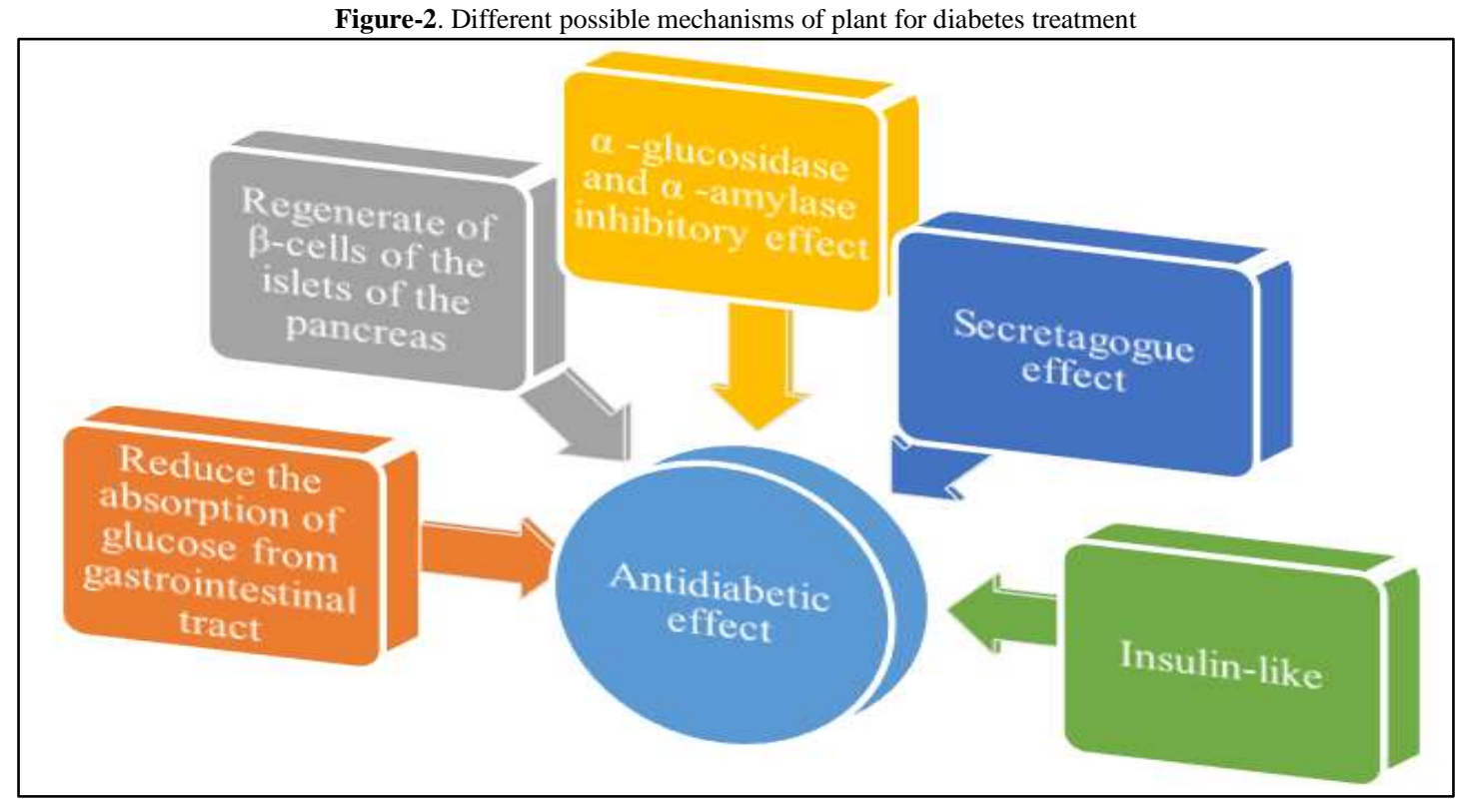

\section{1. $\alpha$-glucosidase and $\alpha$-amylase Inhibitory Effect}

$\alpha$-glucosidase and $\alpha$-amylase are two enzymes that help digest carbohydrates. While pancreatic $\alpha$-amylases hydrolyze the internal 1,4-glycosidic bond of starch to produce maltose and glucose, $\alpha$-glucosidases hydrolyze both starch and sucrose to glucose. These mechanisms are known to occur in the upper region of the small intestine, as well as the pancreas, and have the potential to boost plasma glucose levels, particularly in diabetic patients [38]. By reducing the hydrolysis of starch, $\alpha$-amylase inhibitors are one of the medications that decrease hyperpostprandial blood glucose. By delaying or interrupting glucose absorption as a result of decreasing starch digestion, inhibition of $\alpha$-amylase aids to improve symptoms of type 2 diabetes. Although the primary goal of $\alpha$-amylase inhibition is to delay the formation of maltose and glucose, it can also slow the action of $\alpha$-glucosidase by removing the enzyme's substrate [39].

\subsubsection{Hagenia abyssinica}

Hagenia abyssinica (HA) is a multipurpose dioecious tree in the plant family of Rosaceae. It is a tree growing up to $20 \mathrm{~m}$. The species occurs in Kenya, Tanzania, Uganda, Sudan, Congo, Malawi, Burundi and Rwanda [40]. The in vitro $\alpha$-amylase inhibition of the crude extract and solvent fractions of $H A$ were evaluated by using 3,5dinitrosalicylic acid (DNSA) assay model. The result of $\alpha$-amylase enzyme inhibition activity was found in a dosedependent manner [41, 42]. In a recent study (2021), the crude extract and solvent fractions of HA leaves were examined for in vitro $\alpha$-amylase and $\alpha$-glucosidase inhibitory effects. The crude extract was found to be the most active fraction in the $\alpha$-amylase inhibition experiment. At concentration of $500 \mathrm{~g} / \mathrm{ml}$, the crude extract showed 


\section{Sumerianz Journal of Medical and Healthcare}

percentage inhibition of $74.52 \%$, with an $\mathrm{IC}_{50}$ of $14.52 \mu \mathrm{g} \cdot \mathrm{mL}^{-1}$. The highest $\alpha$-glucosidase inhibitory activity was shown by the crude extract and aqueous fraction ( $\mathrm{IC}_{50}: 15.89 \mu \mathrm{g} \cdot \mathrm{mL}^{-1}$ and $11.67 \mu \mathrm{g} \cdot \mathrm{mL}^{-1}$, respectively) [43].

Figure-3. Standing Hagenia abyssinica tree and its flowers [40].

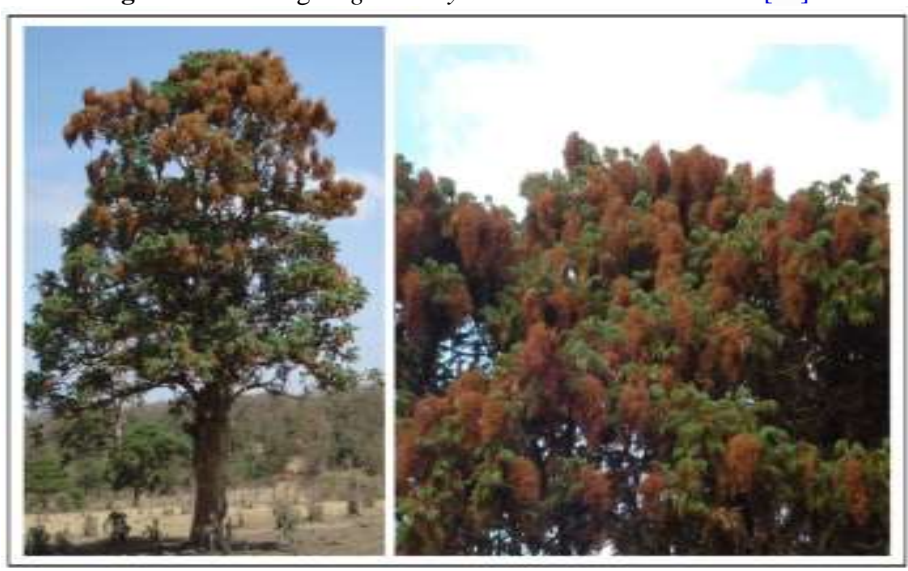

\subsubsection{Canarium tramdenum}

Canarium tramdenum $(C T)$ fruits are widely consumed as meals and cooking components in Vietnam, Laos, and China's southeast area, while the leaves are traditionally used to treat diarrhea and rheumatism. Quan, et al. [44] looked into the possibility of using $C T$ bark as antioxidants, as well as $\alpha$-amylase and $\alpha$-glucosidase inhibitors.

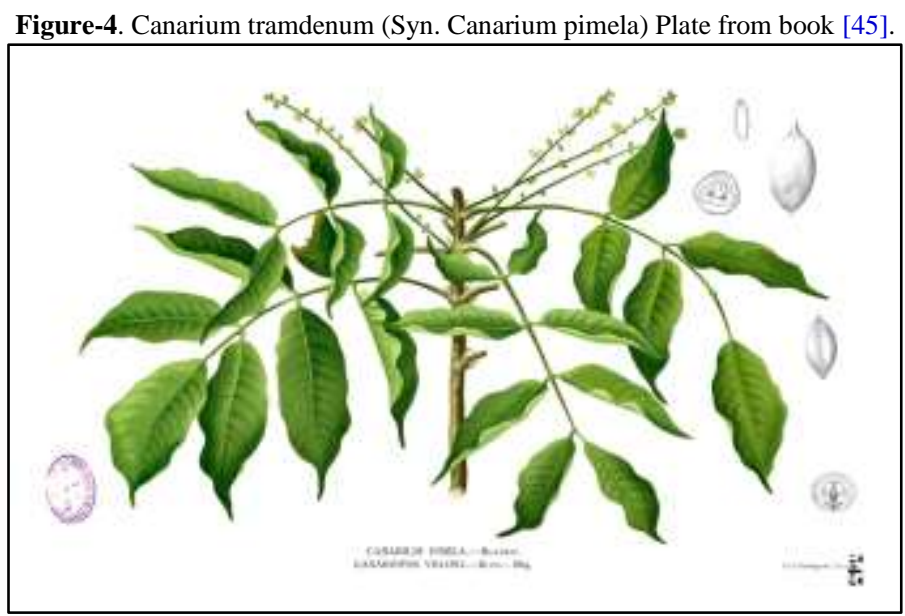

Five different $C T$ bark extracts were tested. In vitro tests revealed that $C T$ bark has high antioxidant and $\alpha$ glucosidase inhibitory activities, according to the study. The extracts had a possible effect on $\alpha$-amylase inhibition and were considerably more effective at inhibiting $\alpha$-glucosidase than acarbose, a common inhibitor used in diabetic treatment. The of both terpenoids and phenolics may be important in inhibiting $\alpha$-amylase and $\alpha$-glucosidase [44].

\subsubsection{Rosa canina $\mathrm{L}$.}

Rosa canina L. (Rosaceae) has long been utilized in Tunisian folk medicine and confectionery. Rosa canina $(R C)$ has traditionally been used to prevent and treat common colds, flu, digestive disturbances, and infections [46]. In Turkish folk medicine, the fruit is considered as the most promising remedy for hemorrhoids and diabetes mellitus [47]. Vitamin C, tocopherols, carotenoids, polyphenols, organic acids, sugars, and essential fatty acids are all found in rose hip, the pseudo-fruit of $R C$. The rose hips of $R C$ have been shown in numerous studies to offer a wide range of bioactivities, including anti-inflammatory, anti-obesity, and anti-diabetic properties [48].

Figure-5. The ripe pseudo fruits, "rose hips", of Rosa canina [48].

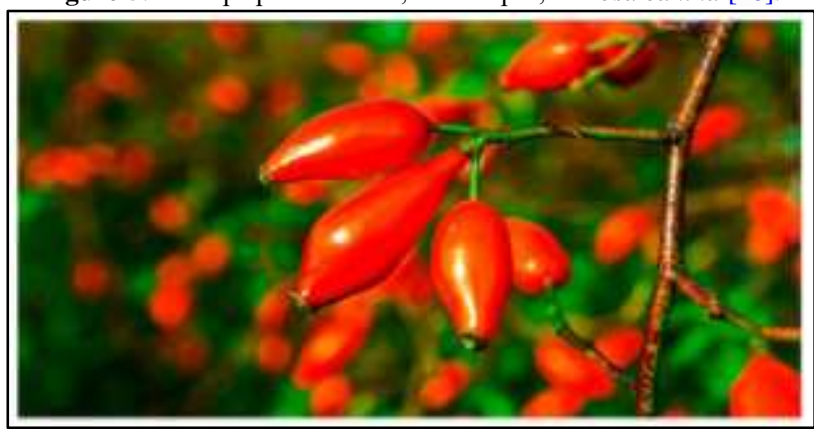




\section{Sumerianz Journal of Medical and Healthcare}

$R C$ methanolic extract has a significant amount of total phenol and flavonoid. Results showed that $R C$ methanolic extract was extremely effective at inhibiting $\alpha$-amylase with a high degree of inhibition. Because of this inhibitory function, $R C$ may be able to postpone starch breakdown after consuming a carbohydrate-dense meal [39]. As well $R C 3$-month administration to type 2 diabetic patients may reduce fasting blood glucose and total cholesterol/HDL-C without any side effect [49].

\subsubsection{Cayratia trifolia}

Cayratia trifolia Linn. Domin syn. Vitis trifolia Linn. (Family:Vitaceae) is a native of India, Asia and Australia [50][50]. The treatment of diabetes-induced rats with $\beta$-sitosterol normalized the altered levels of blood glucose, serum insulin, and testosterone, lipid profile, oxidative stress markers, antioxidant enzymes, insulin receptor (IR), and GLUT4 proteins, according to the findings of a study, Ponnulakshmi, et al. [51]. The findings showed that $\beta$ sitosterol improves glycemic control in the adipose tissue of high fat and sucrose-induced type- 2 diabetic mice through activating IR and GLUT4, and through inhibiting $\alpha$-amylase [51, 52]. As a result, it is clear that $\beta$-sitosterol can be used as an anti-diabetic agent.

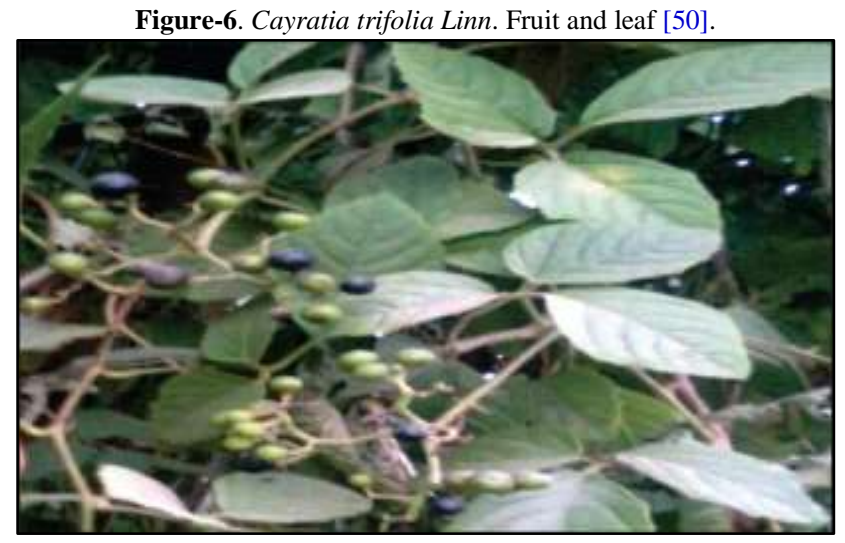

Blood glucose levels increase from 118.60 to $312.70 \mathrm{mg} / \mathrm{dL}$ as a result of $C T$ ethanolic root extract (CTERE) treatment at three distinct doses $(50,250$, and $500 \mathrm{mg} / \mathrm{kg}$ body weight) resulted in a dose-dependent decrease in blood glucose levels. At a $500 \mathrm{mg} / \mathrm{kg}$ body weight dose of CTERE, it dropped to $178.96 \mathrm{mg} / \mathrm{dL}$ from $312.70 \mathrm{mg} / \mathrm{dL}$. Similarly, intraperitoneal streptozotocin injection resulted in a considerable reduction in serum insulin when compared to the control group [53]. The works of Shikha [54] showed that in diabetic rats, both the doses (200 $\mathrm{mg} / \mathrm{kg}$ and $400 \mathrm{mg} / \mathrm{kg}$ ) of ethyl acetate extract were found to be significant $(\mathrm{P}<0.05)$ when compared with control and favourable changes in biochemical parameters were also observed [54]. In contrast the in vivo, antidiabetic test conducted by animal diabetes modeling that has given streptozotocin $150 \mathrm{~g} / \mathrm{kg} \mathrm{BW}$ and $10 \%$ of sucrose solution intraperitoneally showed that the effect of extract 400 and $500 \mathrm{mg} / \mathrm{kg} \mathrm{BW}$ are not different significantly with glibenclamide in reducing blood glucose levels subset of the statistics ANOVA $(p>0.05)$ [55].

\subsubsection{Caralluma europaea}

The medicinal plant Caralluma europaea (CE) belongs to the family Apocynaceae (subfamily Asclepiadaceae). $C E$ is distributed in Morocco, Algeria, Tunisia, Libya, Egypt, Jordan, Spain, and Italy. The different parts of the plant are used traditionally to treat various diseases such as diabetes mellitus, flu, caught, kidney stones [56, 57].

Figure-7. A) habitus of Caralluma europaea (Guss.) N. E. Br; B) C. europaea flower [56].
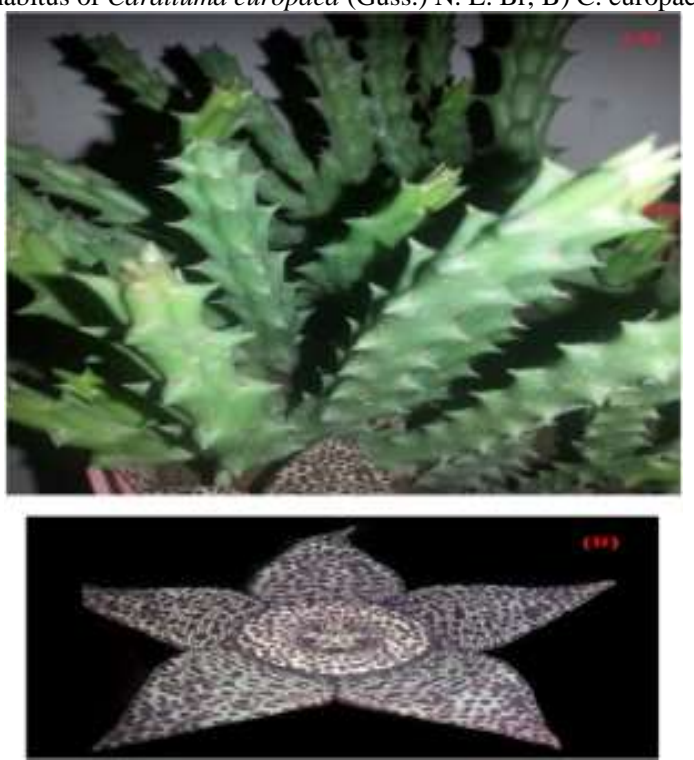


\section{Sumerianz Journal of Medical and Healthcare}

$C E$ extracts showed $66 \%$ inhibition of $\alpha$-glucosidase activity in vitro. Among other mechanism pathways, the antihyperglycemic action of $C E$ may be partially attributed to the intestinal $\alpha$-glucosidase inhibition [57]. Another study was done to investigate the potential and mechanism of the antidiabetic activity of the $C E$ methanolic extract in alloxan-induced diabetic mice [58]. Results showed that the methanol extract prevented the diabetogenic effect of alloxan and decreased significantly the blood glucose level $(P<0.001)$ in treated mice. Morphometric study of pancreas revealed that $C$. europaea extract protected significantly the islets of Langerhans against alloxan-induced tissue alterations [58]. Besides CE, under the genus caralluma other species has showed antidiabetic effect (Caralluma adscendens) [59] and antihyperglycemic effect (Caralluma umbellata) [60].

\subsection{Bioactive Compounds Insulin-Like (insulin mimetic)}

\subsubsection{Momordica charantia}

Momordica charantia (MC), that's also known as bitter melon, utilized as a vegetable, it is also thought to be an herbal remedy that is used in folk medicine. MC is a Cucurbitaceae plant which is a tropical vegetable that is widely grown in Vietnam, India, China, East Africa, South-North Asia, and Central and South America [61, 62]. It has many potential bioactivities, such as anti-inflammatory, anti-oxidant, antiviral, anti-cancer, anti-bacterial, and antidiabetic action, among others, and especially anti-diabetic activity [57].

Figure-8. Pictures show the different morphological of two varieties of Momordica charantia unripe fruit [63].

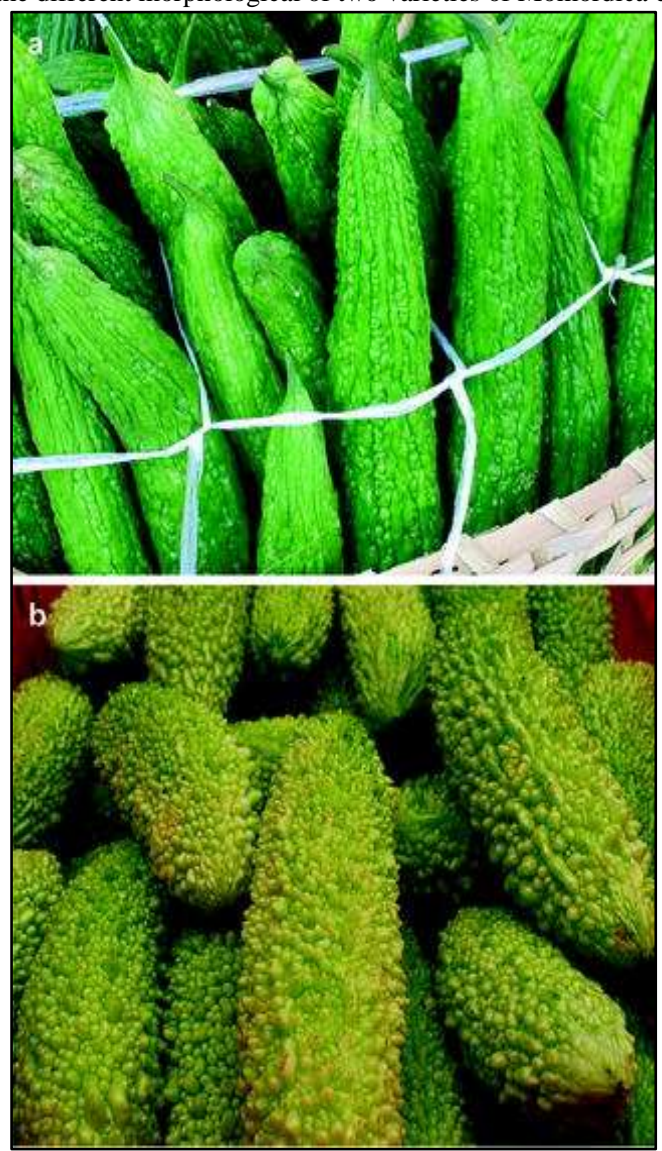

Many studies have been published that show bitter melon active components can help with T2D treatment [6467]. $M C$ contains insulin-like proteins that are similar to human insulin [68]. Many studies have demonstrated that its bioactivities reduce blood glucose levels considerably [69-71]. Bitter melon has also been shown to improve glucose tolerance in normal and diabetic mice, as well as in people, according to these studies. Momordicoside U ( $3 \beta, 7 \beta$ Dihydroxycucurbita-5,23(E)-dien-19-al-25-O- $\beta$-D-glucopyranoside) compound might improve glucose absorption in an in vitro insulin secretion assay by measuring insulin secretion activity [72]. Furthermore, studies of $M C$ have shown the ability of their extracts to regenerate or recover partially destroyed pancreas cells, promoting insulin secretion, and the protection of pancreatic $\beta$-cells [73-76]. Other research looked at the effects of $M C$ extracts on diabetes-related enzymes like alpha-glucosidase and alpha-amylase [77].

\subsubsection{Panax ginseng}

Ginseng (Panax ginseng) Ginseng has long been a well-known traditional plant in Korea, and it has been utilized in folk medicine for a long time. Ginseng is a member of the Panax genus in the Araliaceae family. It is found in Eastern Asia, such as Korea, Eastern Siberia, Northeast China, and North America, where it thrives in milder climates. Many bioactive substances are found in the root of this plant, including triterpene glycosides, or saponins, also known as ginsenosides, Panaxans, vanillic acid, and salicylates. Amino acids, alkaloids, phenols, proteins, polypeptides, and vitamins B1 and B2 have all been found as active constituents in various portions of the plant [78-80]. 


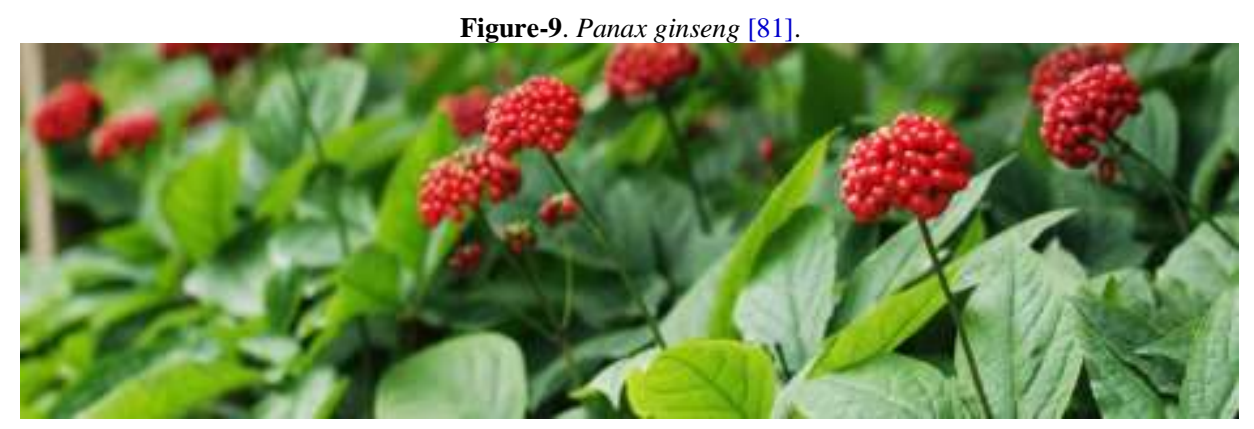

In vitro and in vivo studies on the anti-diabetic properties of Panax ginseng root have been conducted by a number of researchers. Ginseng-specific saponins known as ginsenosides are the most important group of phytochemicals found in Panax ginseng [82]. Ginsenosied Rb2 was found to be the most effective in treating streptozotocin-induced diabetic rats by lowering blood glucose levels [83]. Furthermore, the quantity of ginsenoside $\mathrm{Rg} 2, \mathrm{Rg} 3$, and $\mathrm{Rh} 2$ in fermented red ginseng extracts is higher than in regular ginseng, so that orally administered 100 or $200 \mathrm{mg} / \mathrm{kg}$ extracts dramatically lowered blood glucose levels and boosted plasma insulin levels in streptozotocin-induced diabetic rats [84].

\subsection{Bioactive Compounds Increase Insulin Secretion From $\beta$-cells of Pancreas (secretagogue effect)}

In type 1 diabetes, pancreatic $\beta$-cells are damaged by immunological agents, such as cytokines and macrophages or T cells activated by autoimmune responses, while type 2 diabetes results from both insulin resistance and relative insulin deficiency that cannot compensate for the insulin resistance [85]. Therefore, maintaining pancreatic $\beta$-cell function may be of high importance for the prevention and treatment of diabetes [86].

\subsubsection{Allium Genus}

The genus allium contains more than 500 species [21]. Having different biological effects, the activities of Allium vegetables are mainly attributed to their contents in organosulphur compounds [87, 88]. Even many of the species have demonstrate antidiabetic activity, we will interest on the most important species used in our daily foods. For instance, the essential oils of the green parts of Allium ampeloprasum decrease significantly the glucose level [87], while the methanolic extract of Allium ascalonicum decreased blood glucose level in alloxan diabetic rats [89].

\subsubsection{Allium cepa Linn}

Allium cepa Linn. $(A C)$, also known as onion, belongs to the Liliaceae family. Extracts from $A C$ have been shown to induce a variety of bioactivities, including anti-inflammatory, antioxidant, and anti-diabetic properties. [22, 90-93] S-methyl cysteine sulfoxide and S-allyl cysteine sulfoxide, which are found in the bulb, have been shown to have anti-diabetic properties [91]. Again many mechanisms can be responsible of the antidiabetic activity but secretagogue effect is the most relevant.

\subsubsection{Allium sativum Linn.}

Allium sativum Linn., generally known as garlic, is a member of the Allium family of plants. Garlic has been demonstrated to be used to treat a variety of ailments for over a thousand years [94]. It has been discovered to have a wide range of biological effects, including anti-tumor activity, antibacterial action, immunomodulatory and antihyperglycemic activity, according to various scientific research investigations [95]. Alkaloids, flavonoids, cardiac glycosides, terpenes and steroids, resin, alliin, allicin, ajoene, diallyl sulfide, enzymes, B-vitamins, proteins, minerals, saponins, flavonoids, and so on, are all active phytochemicals found in raw garlic [22, 93, 94]. 
Figure-10. A scheme of the anti-diabetic effect of garlic, showing possible roles of garlic in the development of diabetes and its com plications [96].

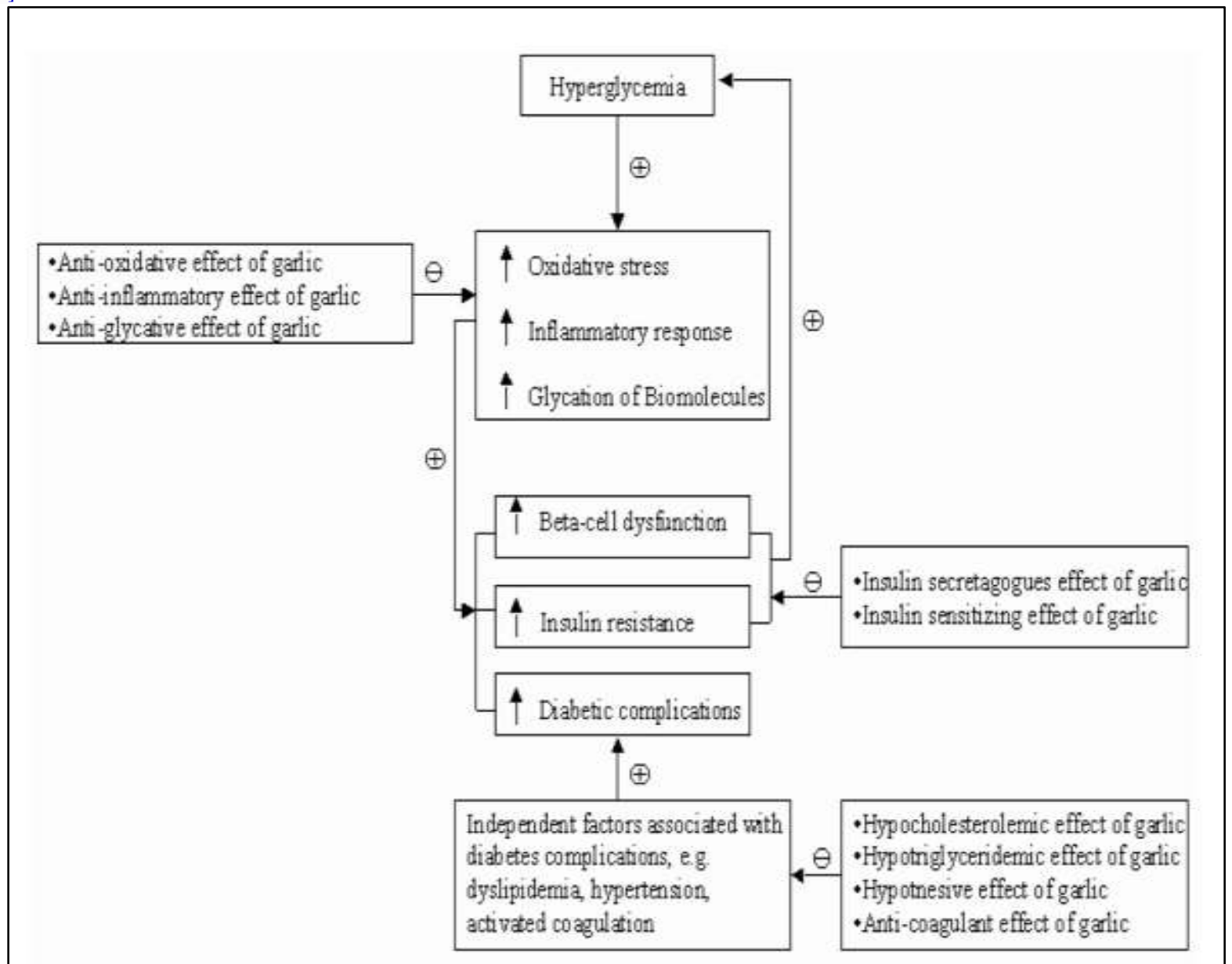

Garlic's biological activity in anti-diabetics has been proven to control the excretion of insulin from $\beta$-cells, promote glucose tolerance, and glycogen synthesis. For example, the beneficial chemicals allyl propyldisulfide and S-methylcysteine sulfoxide, which are derived from garlic, can lower blood glucose levels. Furthermore, the ethanol extract from garlic demonstrated anti-diabetic effect by restoring insulin delayed response [22, 97].

Figure-11. Garlic (A. sativum) and onion (A. Cepa) [97].

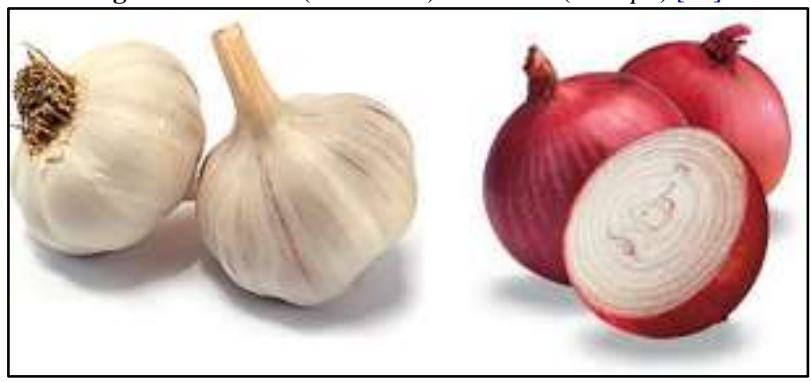

\subsubsection{Aloe vera L. Burm}

Aloe vera L. Burm. (Asphodelaceae) is a well-known and widely used medical plant, particularly in the cosmetics industry and as an anti-diabetic agent [98, 99]. It is indigenous to Africa and the Mediterranean. Alkaloids, flavonoids, tannins, phenols, saponins, carbohydrates, vitamins and minerals, and various other aromatic chemicals are phytoconstituents in the plant have been shown to have antioxidant, antibacterial, antidiabetic, anti-cancer, and other pharmacological properties. As a result, scientists have continued to study the biological activities of this plant in order to develop modern and traditional medicine $[22,100]$. 


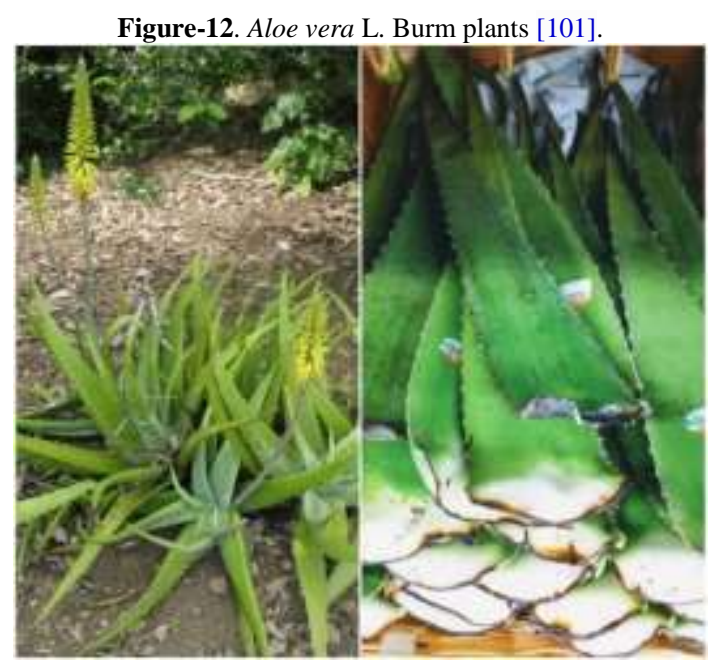

Diabetic mice given oral Aloe vera water extract experienced dramatic decrease in blood glucose levels. Aloe vera water extract is anti-diabetic and has less side effects, according to statistical analysis. Furthermore, Aloe vera's lower cost is a key benefit in the creation of diabetic mellitus medicine [22, 102].

\subsection{Bioactive Compounds Regenerate of $\beta$-cells of the islets of the pancreas \\ 3.4.1. Pterocarpus marsupium}

Pterocarpus marsupium (Fabaceae) is a plant that is frequently used to treat a variety of metabolic diseases, including hyperglycemia. P. marsupium, like most plants, contains a lot of phenolic and flavonoid components [103]. This plant is said to include alkaloids, steroids, terpenoids, tannins, amino acids, proteins, and other compounds. Epicatechin, one of the plant's possible anti-diabetic components, has been effectively identified. It's also said to be high in polyphenolic chemicals, which are thought to be important bioactive compounds. These chemicals have a wide range of biological action, including anti-inflammatory, anti-bacterial, anti-oxidant activities, and antidiabetic activity [104-107].

Figure-13. Pterocarpus marsupium: (a) whole plant and (b) leaves [22].

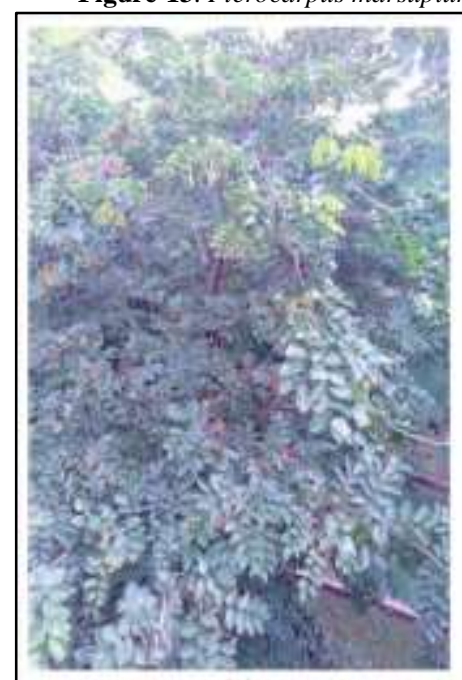

(a)

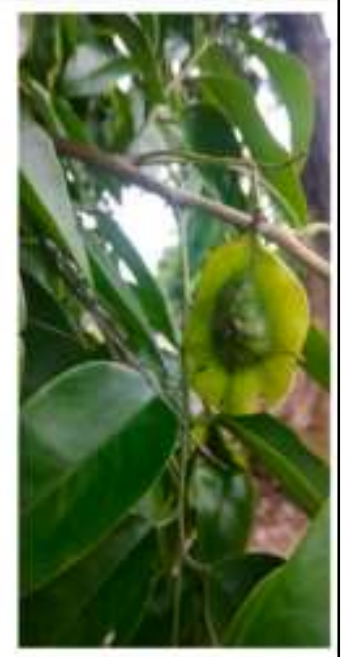

(b)

Diabetic patients were given an extract of $P$. marsupium, which had a considerable anti-hyperglycemic effect. After being tested for five days on alloxan-induced diabetic rats, the ethanolic extract of $P$. marsupium demonstrated blood sugar reducing effects, indicating that it has a strong anti-diabetes impact. It was discovered to be useful in decreasing blood sugar levels. Epicatechin, a compound derived from P. marsupium, was found to have the potential to regenerate $\beta$-cells in the pancreas islets. Furthermore, it has been claimed that the aqueous extract of this plant can stimulate insulin production and increase glucose absorption, making it an antidiabetic treatment [22].

\subsubsection{Tinospora cordifolia and Tinospora crispa}

The Menispermaceae family includes Tinospora cordifolia (T. cordifolia) and Tinospora crispa (T. crispa.) $T$. cordifolia a plant native to India and is mostly found in tropical countries like Myanmar and Sri Lanka [108]. For a long time, it has been one of the most important medications in Indian Systems of Medicine, since it has been recorded as the primary source of treatment for many disorders in folk medicine, including fever, dyspepsia, and urinary diseases [22]. 


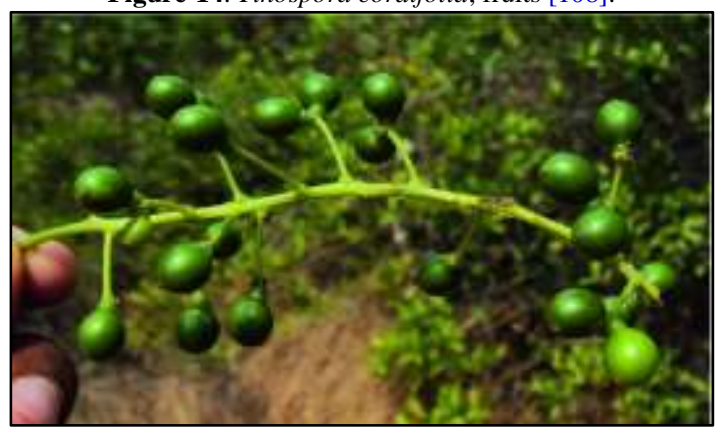

T. cordifolia has been shown to contain a variety of secondary metabolites, including alkaloids, terpenoids, essential oils, glycosides, steroids, phenolic components, aliphatic compounds, and polysaccharides, among others. These active chemicals have been tested for antiseptic, anti-inflammatory, anti-cancer, antibacterial, and antidiabetic properties. Aqueous, alcohol and chloroform extracts exerted significant hypoglycemic and antihyperglycemic effects in normal and diabetic animals [109-113].

T. cordifolia, which contains polysaccharide, has been shown to have $\beta$-cell regeneration characteristics, which could lead to the development of an anti-diabetic drug with few adverse effects [114]. Promotion of insulin secretion and inhibition of gluconeogenesis have been reported after the oral treatment with T. cordifolia root extract for two weeks in induced type 2 diabetic rats leading to improvement in blood glucose level management in the body [115].

Regarding T. crispa, it has been found to be a rich source of secondary metabolites, which are classified as alkaloids, flavonoids, terpenoids, lignans, and steroids. An orally administered extract of $T$. crispa could have an anti-diabetic effect. The mechanisms of these actions were hypothesized, implying that this plant may promote insulin production by modulating the concentration of $\mathrm{Ca}^{2+}$ in $\beta$-cells. T. crispa extracts increased the glucose transport activity of L6 myotubes in Noipha's experiment [116, 117].

\subsubsection{Gymnema sylvestre}

In Ayurveda, diabetes is referred to as "Madhumeh". That's why this plant is also called Madhunashini in Kannada or Gurmar in Hindi for "destroyer of sugar" [118]. Gymnema sylvestre (G. sylvestre) belongs to the Apocynaceae family. It was considered among the major botanicals to treat diabetes in the Ayurvedic system of medicine as well ase included in Indian Pharmacopoeia as an anti-diabetic plant [119]. the antihyperglycemic effect of $G$. sylvestre can be, at least partly, attributed to the inhibition of $\alpha$-glucosidase by its gymnemic acids [120].

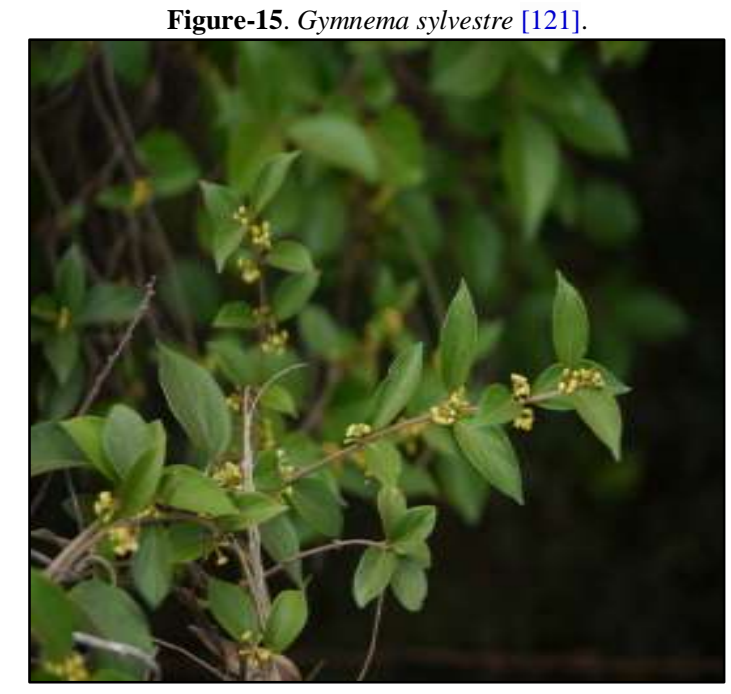

Gymnemic acids, a series of triterpenoid saponins isolated and identified effectively, are the main biological active element in G. sylvestre. Gymnemic acids' action in diabetic treatment has been reported to be able to stimulate pancreatic cell production, thereby increasing insulin production, increase insulin sensitivity and insulin activity, and help to control and stabilize blood glucose levels in the body, according to the literature. Gymnemic acids have also been shown to limit glucose absorption in the small intestine and the conversion of glycogen in living cells to glucose molecules in the blood. The mentioned mechanisms have been suggested to explain G. sylvestre's antidiabetic action. The aqueous extract of G. sylvestre leaf informed hypoglycemic effects in normal and alloxaninduced diabetic mice by lowering glucose levels [122]. Other research on G. sylvestre extracts revealed that via permeabilizing the $\beta$-cell, this extract could induce insulin release in vitro [22].

\subsection{Bioactive Compounds Reduce the Absorption of Glucose From Gastrointestinal Tract}

Some natural compounds improve glucose homeostasis by reducing the absorption of glucose from the intestine and permitting their loss in urine. 


\subsubsection{Cyamopsis tetragonoloba}

The Fabaceae family includes Cyamopsis tetragonoloba (C. tetragonoloba) sometimes known as Cluster Bean or Guar. It had a minor antihyperglycemic effect on blood glucose level [123] in normal fasting rats due to the presence of flavonoids and other phenolic compounds in the plant, but the blood glucose-lowering effect was considerable in alloxan-induced hyperglycemic rats.

Figure-16. Fresh Plant of Cyamopsis tetragonoloba with pods; A-fresh pods, B-dried pods [124].
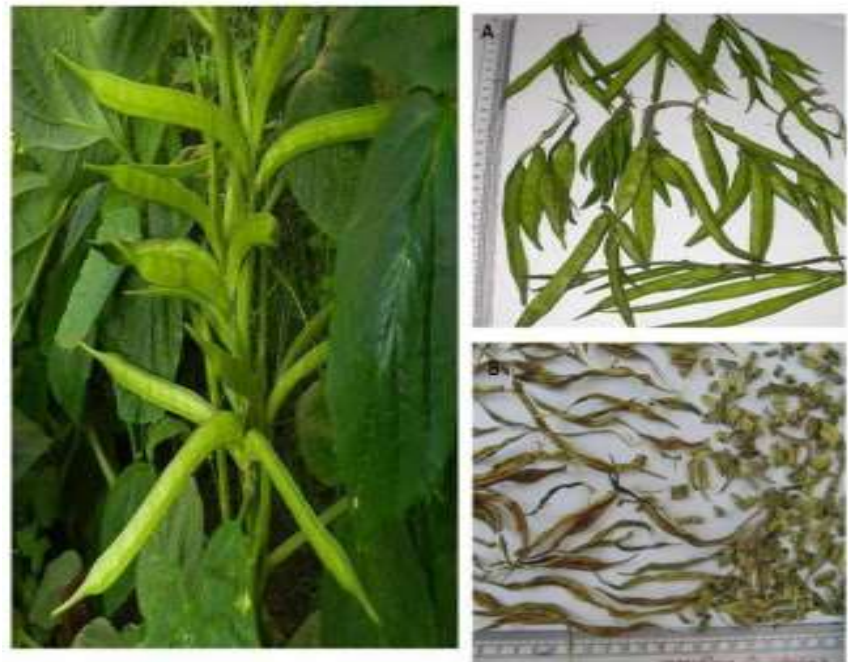

Other research has found that this herb can increase insulin release and lower HbA1c levels. Polyphenols found in $C$. tetragonoloba beans were hypoglycemic and protected $\beta$-cells. As a result, this plant may be evaluated for use in the treatment of type 2 diabetes [22, 125].

\subsubsection{Ocimum sanctum}

Ocimum sanctum (O. sanctum) is a Lamiaceae plant that is usually referred to as "Sacred basil" or "Holy basil." It has long been used in traditional herbal medicine against Diabetes [126-129]. An experiment revealed that the ethanol extract could lower blood glucose levels while increasing insulin production. Furthermore, an in vivo trial revealed that the $O$. sanctum extract improved oral glucose tolerance, decreased blood glucose, and increased glycogen production in the liver. Leaf power extract was found to lower plasma glucose levels due to the presence of several active phytochemicals including as eugenol, carvacrol, linalool, caryophylline, and $\beta$-sitosterol, all of which have been researched for their powerful hypoglycemic effects. In vivo testing revealed the antidiabetic and hypoglycemia properties of a triterpenoid derived from $O$. sanctum in the other study [22]

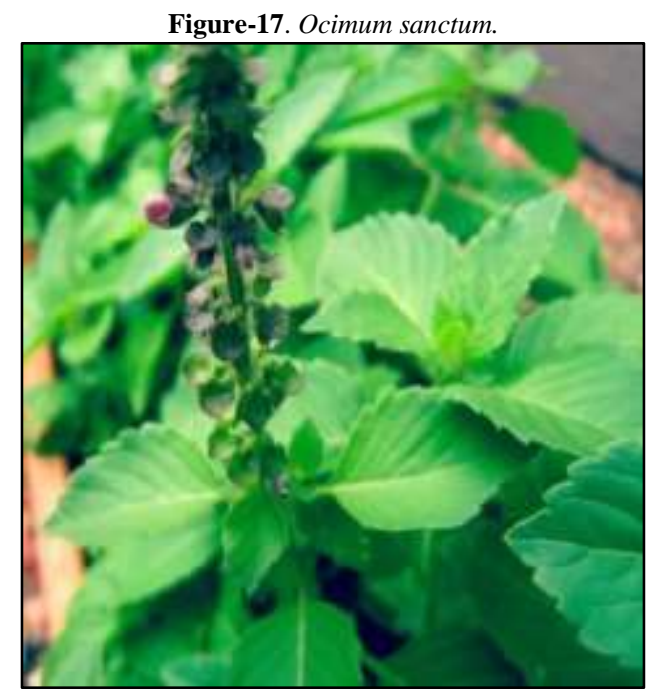

\subsubsection{Aegle marmelos (L.)}

Aegle marmelos (commonly known as Bael, golden apple) was formerly described to have anti-hyperglycemic activity [130, 131]. The results show that anti-hypoglycemic effect is mediated by inhibiting the digestion and absorption of carbohydrates and improving the action of insulin, which takes up glucose in peripheral tissues. In the in situ perfused rat intestine model, a marked reduction in glucose absorption was observed. The extract was also found to inhibit the effects of both $\alpha$-amylase and the intestinal disaccharidase enzyme [130]. 


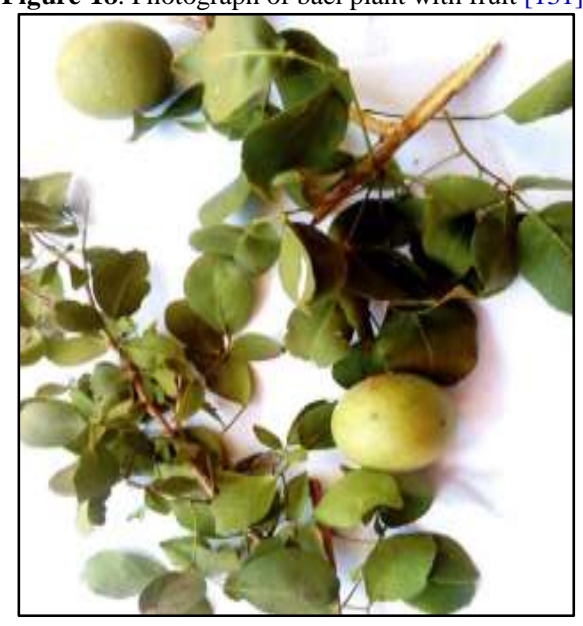

\section{Conclusion}

Diabetes is a major degenerative disease that is a worldwide health concern, that is rapidly growing in prevalence and necessitating the search for products with fewer side effects and less cost than the already marketed drugs. From 11.3 million cases to 102.9 million cases worldwide, diabetes has increased by $102.9 \%$ [132]. Inadequate treatment of diabetes can lead to a number of problems that are costly both financially and in terms of human suffering. Many traditional treatments have been observed as a result of the negative effects of modern therapies. In addition, herbal extracts can now be utilized in combination with established medications for combinatorial therapy. Each herb has its own unique components that can help reduce diabetic complications and lower blood sugar levels. Medicinal products from endemic plants have been examined for their anti-diabetic effects and several studies have found evidence of medicinal plants' antidiabetic benefits, even if further research is needed to fully understand the mechanism. The isolation and identification of bioactive phytochemicals from these plants is critical for better understanding of anti-diabetic functional foods and medication development. According to the literature, the pharmaceutical industry has paid much more attention to the use of phytochemical elements of medicinal plants.

\section{Acknowledgments}

The authors gratefully acknowledge the financial support from Lebanese University (Faculty of Pharmacy).

\section{References}

[1] Salmerón-Manzano, E., Garrido-Cardenas, J. A., and Manzano-Agugliaro, F., 2020. "Worldwide research trends on medicinal plants." Int. J. Environ. Res. Public Health, vol. 17, p. 3376. Available: https://doi.org/10.3390/ijerph17103376

[2] Balandrin, M. F., Kinghorn, A. D., and Farnsworth, N. R., 1993. "Plant-derived natural products in drug discovery and development. In: Human medicinal agents from plants." American Chemical Society, vol. 534, pp. 2-12. Available: DOI: 10.1021/bk-1993-0534.ch001

[3] Aye, M. M., Aung, H. T., Sein, M. M., and Armijos, C., 2019. "A Review on the Phytochemistry, Medicinal Properties and Pharmacological Activities of 15 Selected Myanmar Medicinal Plants." Mol Basel Switz, vol. 24, p. E293. Available: https://doi.org/10.3390/molecules24020293

[4] Anand, U., Jacobo-Herrera, N., Altemimi, A., and Lakhssassi, N., 2019. "A comprehensive review on medicinal plants as antimicrobial therapeutics: Potential avenues of biocompatible drug discovery." Metabolites, vol. 9, p. 258. Available: https://doi.org/10.3390/metabo9110258

[5] Rawat, P., Singh, P. K., and Kumar, V., 2017. "Evidence based traditional anti-diarrheal medicinal plants and their phytocompounds." Biomed Pharmacother, vol. 96, pp. 1453-1464. Available: https://doi.org/10.1016/j.biopha.2017.11.147

[6] Pitchai, D., Manikkam, R., Rajendran, S. R., and Pitchai, G., 2010. "Database on pharmacophore analysis of active principles, from medicinal plants." Bioinformation, vol. 5, pp. 43-45. Available: https://doi.org/10.6026/9732063000543

[7] Formagio, A. S. N., Vieira, M. C., Volobuff, C. R. F., Silva, M. S., Matos, A. I., Cardoso, C. a. L., Foglio, M. A., and Carvalho, J. E., 2015. "In vitro biological screening of the anticholinesterase and antiproliferative activities of medicinal plants belonging to Annonaceae." Braz. J. Med. Biol. Res., vol. 40, pp. 308-315. Available: https://doi.org/10.1590/1414-431X20144127

[8] Amber, R., Adnan, M., Tariq, A., and Mussarat, S., 2017. "A review on antiviral activity of the Himalayan medicinal plants traditionally used to treat bronchitis and related symptoms." J. Pharm. Pharmacol., vol. 69, pp. 109-122. Available: https://doi.org/10.1111/jphp.12669

[9] Oguntibeju, O. O., 2018. "Medicinal plants with anti-inflammatory activities from selected countries and regions of Africa." J. Inflamm Res., vol. 11, pp. 307-317. Available: https://doi.org/10.2147/JIR.S167789 
[10] Pulikottil, S. J. and Nath, S., 2015. "Potential of clove of Syzygium aromaticum in development of a therapeutic agent for periodontal disease: A review." South Afr. Dent. J., vol. 70, pp. 108-115.

[11] Chang, H. J., Kim, Y. H., Kang, Y. H., Choi, M. H., and Lee, J. H., 2020. "Antioxidant and antibacterial effects of medicinal plants and their stick-type medicinal concentrated beverages." Food Sci. Biotechnol., vol. 29, pp. 1413-1423. Available: https://doi.org/10.1007/s10068-020-00793-9

[12] Xiong, W., Wu, H., Xiong, Y., Liu, B., Xie, Z., Wu, S., Yao, Y., and Yang, Y., 2020. "Network pharmacology-based research of active components of Albiziae flos and mechanisms of Its antidepressant effect." Curr. Med. Sci., vol. 40, pp. 123-129. Available: https://doi.org/10.1007/s11596-020-2155-7

[13] Shrestha, J. T. M., Shrestha, H., Prajapati, M., Karkee, A., and Maharjan, A., 2017. "Adverse effects of oral hypoglycemic agents and adherence to them among patients with type 2 diabetes mellitus in Nepal." $J$. Lumbini Med. Coll., vol. 5, pp. 34-40. Available: https://doi.org/10.22502/jlmc.v5i1.126

[14] Lim, S., Bae, J. H., Kwon, H. S., and Nauck, M. A., 2021. "COVID-19 and diabetes mellitus: from pathophysiology to clinical management." Nat. Rev. Endocrinol, vol. 17, pp. 11-30. Available: https://doi.org/10.1038/s41574-020-00435-4

[15] Rao, M., Sreenivasulu, M., Chengaiah, B., Reddy, K., and Chetty, C., 2010. "Herbal medicines for diabetes mellitus: A review." Int. J. Pharm.Tech. Res., vol. 2, pp. 1883-1892.

[16] Salehi, Ata, V., Anil, K., Sharopov, Ramírez-Alarcón, Ruiz-Ortega, Abdulmajid, Ayatollahi, Tsouh, F., et al., 2019. "Antidiabetic potential of medicinal plants and their active components." Biomolecules, vol. 9, p. 551. Available: https://doi.org/10.3390/biom9100551

[17] Sharifi-Rad, M., Nazaruk, J., Polito, L., Morais-Braga, M. F. B., Rocha, J. E., Coutinho, H. D. M., Salehi, B., Tabanelli, G., Montanari, C., et al., 2018. "Matricaria genus as a source of antimicrobial agents: From farm to pharmacy and food applications." Microbiol, Res., vol. 215, pp. 76-88. Available: https://doi.org/10.1016/j.micres.2018.06.010

[18] Pal, D. and Nayak, A. K., 2020. Bioactive natural products for pharmaceutical applications. Springer Nature.

[19] Sharifi-Rad, M., Roberts, T. H., Matthews, K. R., Bezerra, C. F., Morais-Braga, M. F. B., Coutinho, H. D. M., Sharopov, F., Salehi, B., Yousaf, Z., et al., 2018. "Ethnobotany of the genus TaraxacumPhytochemicals and antimicrobial activity." Phytother Res. PTR, vol. 32, pp. 2131-2145. Available: https://doi.org/10.1002/ptr.6157

[20] Rizvi, S. I. and Mishra, N., 2013. "Traditional indian medicines used for the management of diabetes mellitus." J. Diabetes Res., p. e712092. Available: https://doi.org/10.1155/2013/712092

[21] Abu-Odeh, A. M. and Talib, W. H., 2021. "Middle east medicinal plants in the treatment of diabetes." $A$ Review.Molecules, vol. 26, p. 742. Available: https://doi.org/10.3390/molecules 26030742

[22] Tran, N., Pham, B., and Le, L., 2020. "Bioactive compounds in anti-diabetic plants: from herbal medicine to modern drug discovery." Biology, vol. 9, p. 252. Available: https://doi.org/10.3390/biology9090252

[23] Li, H., Yao, Y., and Li, L., 2017. "Coumarins as potential antidiabetic agents." J. Pharm. Pharmacol., vol. 69, pp. 1253-1264. Available: https://doi.org/10.1111/jphp.12774

[24] Kumar, A., Aswal, S., Semwal, R. B., Chauhan, A., Joshi, S. K., and Semwal, D. K., 2019. "Role of plantderived alkaloids against diabetes and diabetes-related complications: a mechanism-based approach." Phytochem Rev., vol. 18, pp. 1277-1298. Available: https://doi.org/10.1007/s11101-019-09648-6

[25] Mohammed, A., Haroun, K., and Mohamed, E., 2020. "Natural alkaloids and diabetes mellitus: A review." Endocr Metab Immune Disord Drug Targets, vol. 21, pp. 111-130.

[26] Lehner, Z., Stadlbauer, K., Brunmair, B., Adorjan, I., Genov, M., Kautzky-Willer, A., Scherer, T., Scheinin, M., Bauer, L., et al., 2020. "Evidence that the multiflorine-derived substituted quinazolidine 55P0251 augments insulin secretion and lowers blood glucose via antagonism at $\alpha 2$-adrenoceptors in mice." Diabetes Obes Metab, vol. 22, pp. 290-302. Available: https://doi.org/10.1111/dom.13895

[27] Gushiken, L. F., Beserra, F. P., Rozza, A. L., Bérgamo, P. L., Bérgamo, D. A., and Pellizzon, C. H., 2016. "Chemical and biological aspects of extracts from medicinal plants with antidiabetic effects." Rev. Diabet Stud RDS, vol. 13, pp. 96-112. Available: https://doi.org/10.1900/RDS.2016.13.96

[28] Rambaran, T. F., 2020. "Nanopolyphenols: a review of their encapsulation and anti-diabetic effects." $S N$ Appl. Sci., vol. 2, p. 1335. Available: https://doi.org/10.1007/s42452-020-3110-8

[29] AL-Ishaq, R. K., Abotaleb, M., Kubatka, P., Kajo, K., and Büsselberg, D., 2019. "Flavonoids and their antidiabetic effects: Cellular mechanisms and effects to improve blood sugar levels." Biomolecules, vol. 9, p. 430. Available: https://doi.org/10.3390/biom9090430

[30] Kim, S. H., Hyun, S. H., and Choung, S. Y., 2006. "Anti-diabetic effect of cinnamon extract on blood glucose in db/db mice." J. Ethnopharmacol, vol. 104, pp. -123. Available: https://doi.org/10.1016/j.jep.2005.08.059

[31] Barky, A. R. E., Hussein, S. A., Alm-Eldeen, A. E., Mohamed, and yehia, A. H. T. M., 2017. "Saponins and their potential role in diabetes mellitus." Diabetes Manag, vol. 7, p. 148.

[32] Elekofehinti, O. O., 2015. "Saponins: Anti-diabetic principles from medicinal plants - A review." Pathophysiology, vol. 22, pp. 95-103. Available: https://doi.org/10.1016/j.pathophys.2015.02.001

[33] Zheng, T., Shu, G., Yang, Z., Mo, S., Zhao, Y., and Mei, Z., 2012. "Antidiabetic effect of total saponins from Entada phaseoloides (L.) Merr. in type 2 diabetic rats." J. Ethnopharmacol, vol. 139, pp. 814-821. Available: https://doi.org/10.1016/j.jep.2011.12.025 


\section{Sumerianz Journal of Medical and Healthcare}

[34] Kwon, D. Y., Kim, Y. S., Ryu, S. Y., Choi, Y. H., Cha, M. R., Yang, H. J., and Park, S., 2012. "Platyconic acid, a saponin from Platycodi radix, improves glucose homeostasis by enhancing insulin sensitivity in vitro and in vivo." Eur. J. Nutr., vol. 51, pp. 529-540. Available: https://doi.org/10.1007/s00394-011-0236-X

[35] Metwally, N., 2012. "Chemical constituents of the Egyptian Plant Anabasis articulata (Forssk) Moq and its antidiabetic effects on rats with streptozotocin-induced diabetic hepatopathy." J. Appl. Pharm. Sci., pp. 5465. Available: https://doi.org/10.7324/JAPS.2012.2403

[36] Kim, J. J. Y., Xiao, H., Tan, Y., Wang, Z. Z., Paul, Seale, J., and Qu, X., 2009. "The effects and mechanism of saponins of Panax notoginseng on glucose metabolism in 3T3-L1 cells." Am. J. Chin. Med., vol. 37, pp. 1179-1189. Available: https://doi.org/10.1142/S0192415X09007582

[37] Lee, K. T., Jung, T. W., Lee, H. J., Kim, S. G., Shin, Y. S., and Whang, W. K., 2011. "The antidiabetic effect of ginsenoside Rb2 via activation of AMPK." Arch. Pharm. Res., vol. 34, p. 1201. Available: https://doi.org/10.1007/s12272-011-0719-6

[38] Mwakalukwa, R., Amen, Y., Nagata, M., and Shimizu, K., 2020. "Postprandial hyperglycemia lowering effect of the isolated compounds from olive mill wastes - an inhibitory activity and kinetics studies on $\alpha$ glucosidase and $\alpha$-amylase enzymes." ACS Omega, vol. 5, pp. 20070-20079. Available: https://doi.org/10.1021/acsomega.0c01622

[39] Jemaa, H. B., Jemia, A. B., Khlifi, S., Ahmed, H. B., Slama, F. B., Benzarti, A., Elati, J., and Aouidet, A., 2017. "Antioxidant activity and a-amylase inhibitory potential of rosa canina 1." Afr. J. Tradit Complement Altern Med., vol. 14, pp. 1-8. Available: https://doi.org/10.21010/ajtcam.v14i2.1

[40] Assefa, B., Glatzel, G., and Buchmann, C., 2010. "Ethnomedicinal uses of hagenia abyssinica (bruce) j.F. Gmel. Among rural communities of ethiopia." J. Ethnobiol Ethnomedicine, vol. 6, Available: https://doi.org/10.1186/1746-4269-6-20

[41] Kifle, Z. D., Woldeyohanin, A. E., Sema, F. D., Debeb, S. G., Kasahun, A. E., Demeke, C. A., and Belayneh, Y. M., 2021. "In vivo hypoglycemic, antihyperglycemic and antidyslipidemic effects of the solvent fractions of Hagenia abyssinica leaves in mice." Metab Open, vol. 12, p. 100139. Available: https://doi.org/10.1016/j.metop.2021.100139

[42] Kifle, Z. D., Yesuf, J. S., and Atnafie, S. A., 2020. "Evaluation of in vitro and in vivo anti-diabetic, antihyperlipidemic and anti-oxidant activity of flower crude extract and solvent fractions of hagenia abyssinica (rosaceae)." J. Exp. Pharmacol, vol. 12, pp. 151-167 Available: https://doi.org/10.2147/JEP.S249964

[43] Kifle, Z. D., Debeb, S. G., and Belayneh, Y. M., 2021. "In vitro $\alpha$-amylase and $\alpha$-glucosidase inhibitory and antioxidant activities of the crude extract and solvent fractions of hagenia abyssinica leaves." BioMed. Res. Int., p. 6652777. Available: https://doi.org/10.1155/2021/6652777

[44] Quan, N. V., Xuan, T. D., Tran, H. D., Thuy, N. T. D., Trang, L. T., Huong, C. T., Andriana, Y., and Tuyen, P. T., 2019. "Antioxidant, $\alpha$-amylase and $\alpha$-glucosidase inhibitory activities and potential constituents of Canarium tramdenum bark." Molecules, vol. 24, p. $605 . \quad$ Available: https://doi.org/10.3390/molecules24030605

[45] Blanco, F. M., 1880. Canarium tramdenum (Syn. Canarium pimela). Plate From Book.

[46] Jd, N., Mm, L., Fs, Š., Gt, A., Dd, Č. S., Nm, M. D., and In, B., 2016. "Comparative study of biological activities and phytochemical composition of two rose hips and their preserves: Rosa canina L. and Rosa arvensis Huds." Food Chem., p. 192. Available: https://doi.org/10.1016/j.foodchem.2015.07.089

[47] Orhan, N., Aslan, M., Hosbas, S., and Deliorman, O. D., 2009. "Antidiabetic effect and antioxidant potential of Rosa canina fruits." Pharmacogn Mag, vol. 5, p. 309. Available: https://doi.org/10.4103/0973$\underline{1296.58151}$

[48] Winther, K., Hansen, A. S. V., and Campbell-Tofte, J., 2016. "Bioactive ingredients of rose hips (Rosa canina L) with special reference to antioxidative and anti-inflammatory properties: in vitro studies." Bot Targets Ther, vol. 9, pp. 11-23. Available: https://doi.org/10.2147/BTAT.S91385

[49] Hashem, Dabaghian, F., Abdollahifard, M., Khalighi, Sigarudi, F., Taghavi, Shirazi, M., Shojaee, A., Sabet, Z., et al., 2015. "Effects of Rosa canina L. fruit on glycemia and lipid profile in type 2 diabetic patients: a randomized, double-blind, placebo-controlled clinical trial." J. Med. Plants, vol. 14, pp. 95-104.

[50] Kumar, D., Kumar, S., Gupta, J., Arya, R., and Gupta, A., 2011. "A review on chemical and biological properties of Cayratia trifolia Linn. (Vitaceae)." Pharmacogn Rev., vol. 5, pp. 184-188. Available: https://doi.org/10.4103/0973-7847.91117

[51] Ponnulakshmi, R., Shyamaladevi, B., Vijayalakshmi, P., and Selvaraj, J., 2019. "In silico and in vivo analysis to identify the antidiabetic activity of beta sitosterol in adipose tissue of high fat diet and sucrose induced type-2 diabetic experimental rats." Toxicol Mech Methods, vol. 29, pp. 276-290. Available: https://doi.org/10.1080/15376516.2018.1545815

[52] Payghami, N., Jamili, S., Rustaiyan, A., Saeidnia, S., Nikan, M., and Gohari, A. R., 2015. "Alpha-amylase inhibitory activity and sterol composition of the marine algae, Sargassum glaucescens." Pharmacogn Res., vol. 7, pp. 314-321. Available: https://doi.org/10.4103/0974-8490.167893

[53] Mohammed, S. I., Salunkhe, N. S., Vishwakarma, K. S., and Maheshwari, V. L., 2017. "Experimental validation of antidiabetic potential of cayratia trifolia (1.) domin: An indigenous medicinal plant." Indian J. Clin. Biochem, vol. 32, pp. 153-162. Available: https://doi.org/10.1007/s12291-016-0598-1

[54] Shikha, B., 2013. "Preliminary phytochemical studies and evaluation of antidiabetic activity of roots of Cayratia trifolia (L.) Domin in alloxan induced diabetic albino rats." J. Appl. Pharm. Sci., Available: https://doi.org/10.7324/JAPS.2013.30319 
[55] Yusuf, M., Susanty, S., Susanty, S., and Fawwaz, M., 2018. "Antioxidant and antidiabetic potential of Galing stem extract (Cayratia trifolia Domin)." Pharmacogn J., vol. 10, pp. 686-690. Available: https://doi.org/10.5530/pj.2018.4.113

[56] Ouassou, H., Bouhrim, M., Kharchoufa, L., Imtara, H., Daoudi, N., elhouda, Benoutman, A., Bencheikh, N., Ouahhoud, S., et al., 2021. "Caralluma europaea (Guss) N.E.Br.: A review on ethnomedicinal uses, phytochemistry, pharmacological activities, and toxicology." J. Ethnopharmacol, vol. 273, p. 113769. Available: https://doi.org/10.1016/j.jep.2020.113769

[57] Ouassou, H., Zahidi, T., Bouknana, S., Bouhrim, M., Mekhfi, H., Ziyyat, A., Legssyer, A., Aziz, M., and Bnouham, M., 2018. "Inhibition of $\alpha$-glucosidase, intestinal glucose absorption, and antidiabetic properties by Caralluma europaea." Evid Based Complement Alternat Med., p. e9589472. Available: https://doi.org/10.1155/2018/9589472

[58] Dra, L. A., Sellami, S., Rais, H., Aziz, F., Aghraz, A., Bekkouche, K., Markouk, M., and Larhsini, M., 2019. "Antidiabetic potential of Caralluma europaea against alloxan-induced diabetes in mice." Saudi J. Biol. Sci., vol. 26, pp. 1171-1178. Available: https://doi.org/10.1016/j.sjbs.2018.05.028

[59] Maheshu, V., Priyadarsini, D. T., and Sasikumar, J. M., 2014. "Antioxidant capacity and amino acid analysis of Caralluma adscendens (Roxb.) Haw var. fimbriata (wall.) Grav. \& Mayur. aerial parts." J. Food Sci. Technol., vol. 51, pp. 2415-2424. Available: https://doi.org/10.1007/s13197-012-0761-5

[60] Bellamakondi, P. K., Godavarthi, A., and Ibrahim, M., 2014. "Anti-hyperglycemic activity of Caralluma umbellata Haw." BioImpacts BI, vol. 4, pp. 113-116. Available: https://doi.org/10.15171/bi.2014.003

[61] Rathi, S. S., Grover, J. K., and Vats, V., 2002. "The effect of Momordica charantia and Mucuna pruriens in experimental diabetes and their effect on key metabolic enzymes involved in carbohydrate metabolism." Phytother Res. PTR, vol. 16, pp. 236-243. Available: https://doi.org/10.1002/ptr.842

[62] Li, W. L., Zheng, H. C., Bukuru, J., and De Kimpe, N., 2004. "Natural medicines used in the traditional Chinese medical system for therapy of diabetes mellitus." J. Ethnopharmacol, vol. 92, pp. 1-21. Available: https://doi.org/10.1016/j.jep.2003.12.031

[63] Lim, T. K., 2012. Momordica charantia. In: Lim tk (ed) edible medicinal and non-medicinal plants. Netherlands, Dordrecht: Fruits. Springer. pp. 331-368.

[64] Saeed, F., Afzaal, M., Niaz, B., Arshad, M. U., Tufail, T., Hussain, M. B., and Javed, A., 2018. "Bitter melon (Momordica charantia): a natural healthy vegetable." Int. J. Food Prop., vol. 21, pp. 1270-1290. Available: https://doi.org/10.1080/10942912.2018.1446023

[65] Chuang, C. Y., Hsu, C., Chao, C. Y., Wein, Y. S., Kuo, Y. H., and Huang, C., 2006. "Fractionation and identification of 9c, 11t, 13t-conjugated linolenic acid as an activator of PPAR $\alpha$ in bitter gourd (Momordica charantia L." J. Biomed Sci., vol. 13, pp. 763-772. Available: https://doi.org/10.1007/s11373-006-9109-3

[66] Dandawate, P. R., Subramaniam, D., Padhye, S. B., and Anant, S., 2016. "Bitter melon: a panacea for inflammation and cancer." Chin. J. Nat. Med., vol. 14, pp. 81-100. Available: https://doi.org/10.1016/S1875-5364(16)60002-X

[67] Ibrahim, T. A., El-Hefnawy, H. M., and El-Hela, A. A., 2010. "Antioxidant potential and phenolic acid content of certain cucurbitaceous plants cultivated in Egypt." Nat. Prod Res., vol. 24, pp. 1537-1545. Available: https://doi.org/10.1080/14786419.2010.489049

[68] Khanna, P., Jain, S. C., Panagariya, A., and Dixit, V. P., 1981. "Hypoglycemic activity of polypeptide-p from a plant source." J. Nat Prod, vol. 44, pp. 648-655. Available: https://doi.org/10.1021/np50018a002

[69] Sasa, M., Inoue, I., Shinoda, Y., Takahashi, S., Seo, M., Komoda, T., Awata, T., and Katayama, S., 2009. "Activating effect of momordin, extract of bitter melon (Momordica Charantia L.), on the promoter of human PPARס." J. Atheroscler Thromb, vol. 16, pp. 888-892. Available: https://doi.org/10.5551/jat.2790

[70] Dans, A. M. L., Villarruz, M. V. C., Jimeno, C. A., Javelosa, M. A. U., Chua, J., Bautista, R., and Velez, G. G. B., 2007. "The effect of Momordica charantia capsule preparation on glycemic control in Type 2 Diabetes Mellitus needs further studies." J. Clin. Epidemiol, vol. 60, pp. 554-559. Available: https://doi.org/10.1016/j.jclinepi.2006.07.009

[71] Jiang, B., Ji, M., Liu, W., Chen, L., Cai, Z., Zhao, Y., and Bi, X., 2016. "Antidiabetic activities of a cucurbitane-type triterpenoid compound from Momordica charantia in alloxan-induced diabetic mice." Mol. Med. Rep., vol. 14, pp. 4865-4872. Available: https://doi.org/10.3892/mmr.2016.5800

[72] Ma, J., Whittaker, P., Keller, A. C., Mazzola, E. P., Pawar, R. S., White, K. D., Callahan, J. H., Kennelly, E. J., Krynitsky, A. J., et al., 2010. "Cucurbitane-Type Triterpenoids from Momordica charantia." Planta Med., vol. 76, pp. 1758-1761. Available: https://doi.org/10.1055/s-0030-1249807

[73] Kim, K. and Kim, H. Y., 2011. "Bitter melon (Momordica charantia) extract suppresses cytokineinduced activation of MAPK and NF-кB in pancreatic $\beta$-Cells." Food Sci. Biotechnol, vol. 20, pp. 531-535. Available: https://doi.org/10.1007/s10068-011-0074-X

[74] Mahmoud, M. F., El Ashry, F. E. Z. Z., El Maraghy, N. N., and Fahmy, A., 2017. "Studies on the antidiabetic activities of Momordica charantia fruit juice in streptozotocin-induced diabetic rats." Pharm Biol, vol. 55, pp. 758-765. Available: https://doi.org/10.1080/13880209.2016.1275026

[75] Paul, A. and Raychaudhuri, S., 2010. "Medicinal uses and molecular identification of two Momordica charantia Varieties; a review." Electron J. Biol., vol. 6, pp. 43-51.

[76] Singh, N. and Gupta, M., 2007. "Regeneration of $\beta$ cells in islets of Langerhans of pancreas of alloxan diabetic rats by acetone extract of Momordica charantia (Linn.) (bitter gourd) fruits." 


\section{Sumerianz Journal of Medical and Healthcare}

[77] Poovitha, S. and Parani, M., 2016. "In vitro and in vivo $\alpha$-amylase and $\alpha$-glucosidase inhibiting activities of the protein extracts from two varieties of bitter gourd Momordica charantia L." BMC Complement Altern Med, vol. 15, p. 185. Available: https://doi.org/10.1186/s12906-016-1085-1

[78] Attele, A. S., Wu, J. A., and Yuan, C. S., 1999. "Ginseng pharmacology: Multiple constituents and multiple actions." Biochem Pharmacol, vol. 58, pp. 1685-1693. Available: https://doi.org/10.1016/S00062952(99)00212-9

[79] Mancuso, C. and Santangelo, R., 2017. "Panax ginseng and panax quinquefolius: From pharmacology to toxicology." Food Chem Toxicol, vol. 107, pp. 362-372. Available: https://doi.org/10.1016/j.fct.2017.07.019

[80] Xu, W., Choi, H. K., and Huang, L., 2017. "State of panax ginseng research: A global analysis." Molecules, vol. 22, p. 1518. Available: https://doi.org/10.3390/molecules22091518

[81] American Ginseng, 2021. "(Panax quinquefolius) plant profile. In: HerbSpeak." Available: https://herbspeak.com/american-ginseng/

[82] Yu, X., Ye, L., Zhang, H., Zhao, J., Wang, G., Guo, C., and Shang, W., 2015. "Ginsenoside Rb1 ameliorates liver fat accumulation by upregulating perilipin expression in adipose tissue of $\mathrm{db} / \mathrm{db}$ obese mice." J. Ginseng Res., vol. 39, pp. 199-205. Available: https://doi.org/10.1016/j.jgr.2014.11.004

[83] Yokozawa, T., Kobayashi, T., Oura, H., and Kawashima, Y., 1985. "Studies on the mechanism of the hypoglycemic activity of ginsenoside-Rb2 in streptozotocin-diabetic rats." Chem Pharm Bull (Tokyo), vol. 33, pp. 869-872. Available: https://doi.org/10.1248/cpb.33.869

[84] Kim, H. J., Chae, I. G., Lee, S. G., Jeong, H. J., Lee, E. J., and Lee, I. S., 2010. "Effects of fermented red Ginseng extracts on Hyperglycemia in Streptozotocin-induced diabetic rats." J. Ginseng Res., vol. 34, pp. 104-112. Available: https://doi.org/10.5142/jgr.2010.34.2.104

[85] Oh, Y. S., 2015. "Plant-derived compounds targeting pancreatic beta cells for the treatment of diabetes." Evid Based Complement Alternat Med., p. e629863. Available: https://doi.org/10.1155/2015/629863

[86] Henquin, J. C., 2004. "Pathways in beta-cell stimulus-secretion coupling as targets for therapeutic insulin secretagogues." Diabetes, vol. 53, pp. S48-S58. Available: https://doi.org/10.2337/diabetes.53.suppl_3.S48 Selim, Y. A. and Sakeran, M. I., 2014. "Effect of time distillation on chemical constituents and anti-diabetic activity of the essential oil from dark green parts of egyptian Allium ampeloprasum L." J. Essent Oil Bear Plants, vol. 17, pp. 838-846. Available: https://doi.org/10.1080/0972060X.2014.935064

[88] Kim, S., Kim, D. B., Jin, W., Park, J., Yoon, W., Lee, Y., Kim, S., Lee, S., Kim, S., et al., 2018. "Comparative studies of bioactive organosulphur compounds and antioxidant activities in garlic (Allium sativum L.), elephant garlic (Allium ampeloprasum L.) and onion (Allium cepa L.)." Nat. Prod. Res., vol. 32, pp. 1193-1197. Available: https://doi.org/10.1080/14786419.2017.1323211

[89] Moradabadi, L., Montasser, Kouhsari, S., and Fehresti Sani, M., 2013. "Hypoglycemic effects of three medicinal plants in experimental diabetes: Inhibition of rat intestinal $\alpha$-glucosidase and enhanced pancreatic insulin and cardiac glut-4 mRNAs expression." Iran J. Pharm Res. IJPR, vol. 12, pp. 387-397.

[90] Adeleye, O., Okoh, E., Adeleye, A., Mshelbwala, F. M., Adetomiwa, A., Apantaku, J., Aboajah, N., Durotoye, L., and Olukunle, J. O., 2020. "Ameliorative effects of Allium cepa Linn. scaly leaves extract on reproductive dysfunctions in streptozotocin-induced diabetic Wistar rats." J. Istanb Vet Sci., vol. 4, pp. 136144. Available: https://doi.org/10.30704/http-www-jivs-net.811491

[91] Kumari, K. and Augusti, K. T., 2002. "Antidiabetic and antioxidant effects of S-methyl cysteine sulfoxide isolated from onions (Allium cepa Linn) as compared to standard drugs in alloxan diabetic rats." Indian J. Exp. Biol., vol. 40, pp. 1005-1009.

[92] Ozougwu, C. J., 2011. "Anti-diabetic effects of Allium cepa (onions) aqueous extracts on alloxan-induced diabetic Rattus novergicus." J. Med. Plants Res., vol. 5, pp. 1134-1139. Available: https://doi.org/10.5897/JMPR.9000094

[93] Sabiu, S., ., Madende, M., Ajao, A. A., Aladodo, R. A., Nurain, I. O., and Ahmad, J. B., 2019. Chapter 9 The Genus Allium (Amaryllidaceae: Alloideae): Features, Phytoconstituents, and Mechanisms of Antidiabetic Potential of Allium cepa and Allium sativum. In: Watson RR, Preedy VR (eds) Bioactive Food as Dietary Interventions for Diabetes (Second Edition). Academic Press, pp. 137-154.

[94] Saikat, A. S. M., Hossain, R., Mina, F. B., Das, S., Khan, I. N., Mubarak, M. S., and Islam, M. T., 2021. "Antidiabetic effect of garlic." Rev Bras Farmacogn, Available: https://doi.org/10.1007/s43450-02100193-y

[95] Leyva, J. M., Ortega-Ramirez, L. A., and Ayala-Zavala, J. F., 2016. Chapter 49 - Garlic (Allium sativum Linn.) Oils. In: Preedy VR (ed) Essential Oils in Food Preservation, Flavor and Safety. Academic Press, San Diego, pp. 441-446.

[96] Liu, C. T., Sheen, L. Y., and C-K, L., 2007. "Does garlic have a role as an antidiabetic agent? ." Mol. Nutr. Food Res., vol. 51, pp. 1353-1364. Available: https://doi.org/10.1002/mnfr.200700082

[97] Pradeep, S. R. and Srinivasan, K., 2019. Chapter 28 - synergy among dietary spices in exerting antidiabetic influences. In: Watson $r r$, preedy vr (eds) bioactive food as dietary interventions for diabetes. Second Edition ed. Academic Press, pp. 407-424.

[98] Yimam, M., Zhao, J., Corneliusen, B., Pantier, M., Brownell, L., and Jia, Q., 2014. "Blood glucose lowering activity of aloe based composition, UP780, in alloxan induced insulin dependent mouse diabetes model." Diabetol Metab Syndr, vol. 6, p. 61. Available: https://doi.org/10.1186/1758-5996-6-61 


\section{Sumerianz Journal of Medical and Healthcare}

[99] Gutterman, Y. and Chauser-Volfson, E., 2007. "Secondary phenol metabolites (SPhMs), distribution and content of some Aloe species, originated from arid zones of south africa: A review." Am. J. Food Technol, vol. 2, pp. 555-569. Available: https://doi.org/10.3923/ajft.2007.555.569

[100] Muñiz-Ramirez, A., Perez, R. M., Garcia, E., and Garcia, F. E., 2020. "Antidiabetic activity of Aloe vera leaves." Evid Based Complement Alternat Med., p. e6371201. Available: https://doi.org/10.1155/2020/6371201

[101] Vandebroek, I. and Picking, D., 2020. Aloe vera (l.) burm.F. (asphodelaceae). In: Vandebroek i, picking d (eds) popular medicinal plants in portland and kingston. Jamaica. Springer: International Publishing, Cham. pp. 13-26.

[102] Yagi, A., Hegazy, S., Kabbash, A., and Wahab, E. E., 2009. "Possible hypoglycemic effect of Aloe vera L. high molecular weight fractions on type 2 diabetic patients." Saudi Pharm. J., vol. 17, pp. $209-215$. Available: https://doi.org/10.1016/j.jsps.2009.08.007

[103] Gulati, V., Harding, I. H., and Palombo, E. A., 2012. "Enzyme inhibitory and antioxidant activities of traditional medicinal plants: Potential application in the management of hyperglycemia." BMC Complement Altern Med, vol. 12, p. 77. Available: https://doi.org/10.1186/1472-6882-12-77

[104] Adinarayana, D. and Syamasundar, K. V., 1982. "A new sesquiterpene alcohol from Pterocarpus marsupium." Phytochemistry, vol. 21, pp. 1083-1085. Available: https://doi.org/10.1016/S0031$\underline{9422(00) 82421-8}$

[105] Chakravarthy, B. K., Saroj, G., Gambhir, S. S., and Gode, K. D., 1980. "Pancreatic beta cell regeneration a novel antidiabetic mechanism of Pterocarpus marsupium roxb." Indian J. Pharmacol, vol. 12, p. 123.

[106] Halagappa, K., Girish, H. N., and Srinivasan, B. P., 2010. "The study of aqueous extract of Pterocarpus marsupium Roxb. on cytokine TNF- $\alpha$ in type 2 diabetic rats." Indian J. Pharmacol, vol. 42, pp. 392-396. Available: https://doi.org/10.4103/0253-7613.71922

[107] Rahman, M., Mujahid, M., Siddiqui, M., Siddiqui, M., Arif, M., Eram, S., Khan, A., and Azeemuddin, M., 2018. "Ethnobotanical uses, phytochemistry and pharmacological activities of Pterocarpus marsupium: A Review." Pharmacogn J., vol. 10, pp. s1-s8. Available: https://doi.org/10.5530/pj.2018.6s.1

[108] Akbar, S., 2020. Tinospora cordifolia (Willd.) Miers ex Hook. F. \& Thoms (Menispermaceae). In: Akbar S (ed) Handbook of 200 Medicinal Plants: A Comprehensive Review of Their Traditional Medical Uses and Scientific Justifications. Cham: Springer International Publishing. pp. 1811-1824.

[109] Chougale, A. D., Ghadyale, V. A., Panaskar, S. N., and Arvindekar, A. U., 2009. "Alpha glucosidase inhibition by stem extract of Tinospora cordifolia." J. Enzyme Inhib. Med. Chem., vol. 24, pp. 998-1001. Available: https://doi.org/10.1080/14756360802565346

[110] Grover, J. K., Vats, V., and Rathi, S. S., 2000. "Anti-hyperglycemic effect of Eugenia jambolana and Tinospora cordifolia in experimental diabetes and their effects on key metabolic enzymes involved in carbohydrate metabolism." J. Ethnopharmacol, vol. 73, pp. 461-470. Available: https://doi.org/10.1016/S0378-8741(00)00319-6

[111] Grover, J. K., Vats, V., Rathi, S. S., and Dawar, R., 2001. "Traditional Indian anti-diabetic plants attenuate progression of renal damage in streptozotocin induced diabetic mice." J. Ethnopharmacol, vol. 76, pp. 233238. Available: https://doi.org/10.1016/S0378-8741(01)00246-X

[112] Kar, A., Choudhary, B. K., and Bandyopadhyay, N. G., 2003. "Comparative evaluation of hypoglycaemic activity of some Indian medicinal plants in alloxan diabetic rats." J. Ethnopharmacol, vol. 84, pp. 105-108. Available: https://doi.org/10.1016/S0378-8741(02)00144-7

[113] Wadood, N., Wadood, A., and Shah, S. A. W., 1992. "Effect of Tinospora cordifolia on blood glucose and total lipid levels of normal and alloxan-diabetic rabbits." Planta Med., vol. 58, pp. 131-136. Available: https://doi.org/10.1055/s-2006-961414

[114] Sangeetha, M. K., Balaji, Raghavendran, H. R., Gayathri, V., and Vasanthi, H. R., 2011. "Tinospora cordifolia attenuates oxidative stress and distorted carbohydrate metabolism in experimentally induced type 2 diabetes in rats." J. Nat. Med., vol. 65, p. 544. Available: https://doi.org/10.1007/s11418-011-0538-6

[115] Ahmad, W., Jantan, I., and Bukhari, S. N. A., 2016. "Tinospora crispa (L.) Hook. f. \& Thomson: A Review of its ethnobotanical, phytochemical, and pharmacological aspects." Front Pharmacol, vol. 7, p. 59. Available: https://doi.org/10.3389/fphar.2016.00059

[116] Noiphaa, K., Ratanachaiyavongc, S., Purintrapibanc, J., and Herunsaleed, A., 2011. "Effect of Tinospora crispa on glucose uptake in skeletal muscle: role of glucose transporter 1 expression and extracellular signal-regulated kinase1/2 activation." Asian Biomed, vol. 5, pp. 361-369. Available: https://doi.org/10.5372/1905-7415.0503.047

[117] Klangjareonchai, T. and Roongpisuthipong, C., 2011. "The effect of Tinospora crispa on serum glucose and insulin levels in patients with type 2 diabetes mellitus." J. Biomed Biotechnol, p. e808762. Available: https://doi.org/10.1155/2012/808762

[118] Joy, S., 2021. "Health secrets of ayurveda \#8: Gurmar or madhunashini." Available: https://ca.movies.yahoo.com/health-secrets-of-ayurveda-8-gurmar-or-madhunashini-063234539.html

[119] Singh, V. K., Umar, S., Ansari, S. A., and Iqbal, M., 2008. "Gymnema sylvestre for diabetics." J. Herbs Spices Med. Plants, vol. 14, pp. 88-106. Available: https://doi.org/10.1080/10496470802341508

[120] Alkefai, N. H. A., Amin, S., Sharma, M., Ahamad, J., and Mir, S. R., 2019. "New olean-15-ene type gymnemic acids from Gymnema sylvestre (Retz.) R.Br. and their antihyperglycemic activity through $\alpha$ glucosidase inhibition." Phytochem Lett., vol. 32, pp. 83-89. Available: https://doi.org/10.1016/j.phytol.2019.05.005 
[121] Bienfaits du gymnéma 2021. "vertus et contre-indications - Ooreka. In: Ooreka.fr. //phytotherapie.ooreka.fr/astuce/voir/609095/bienfaits-du-gymnema."

[122] Sathya, S., Kokilavani, R., and Gurusamy, K., 2008. "Hypoglycemic effect of Gymnema sylvestre (retz.,) R.Br leaf in normal and alloxan induced diabetic rats." Anc. Sci. Life, vol. 28, pp. 12-14.

[123] Mukhtar, H. M., Ansari, S. H., Bhat, Z. A., and Naved, T., 2006. "Antihyperglycemic activity of cyamopsis tetragonoloba. Beans on blood glucose levels in alloxan-induced diabetic rats." Pharm Biol., vol. 44, pp. 10-13. Available: https://doi.org/10.1080/13880200500509025

[124] Ramasheshan, S., Pitchaiah, P., Maramreddy, P., Bharti, V., Ramakrishana, K., Gaddam, V., Tewari, D., Mangal, A., Padhi, M., et al., 2016. "Pharmacognostical standardization of Goraksha pods: an important nutritive and antidiabetic plan." Pharmacogn J., vol. 8, pp. 424-429. Available: https://doi.org/10.5530/pj.2016.5.2

[125] Jamshed, M., Ali, S. T., Rizwani, G. H., Zahid, H., and Asif, S. T., 2018. "Pharmacognostic evaluation of pods of Cyamopsis tetragonoloba L." Int. J. Herb. Med., vol. 6, pp. 51-53.

[126] Chopra, R. N., Nayar, S. L., Chopra, I. C., and Varma, B. S., 1956. Glossary of Indian Medicinal Plants vol. 58. New Delhi: Council of Scientific and Industrial Research.

[127] Hannan, J. M. A., Ojo, O. O., Ali, L., Rokeya, B., Khaleque, J., Akhter, M., Flatt, P. R., and Abdel-Wahab, Y. H. A., 2015. "Actions underlying antidiabetic effects of Ocimum sanctum leaf extracts in animal models of type 1 and type 2 diabetes." Eur. J. Med. Plants, pp. 1-12. Available: https://doi.org/10.9734/EJMP/2015/11840

[128] Malapermal, V., Botha, I., Krishna, S. B. N., and Mbatha, J. N., 2017. "Enhancing antidiabetic and antimicrobial performance of Ocimum basilicum, and Ocimum sanctum (L.) using silver nanoparticles." Saudi J. Biol. Sci., vol. 24, pp. 1294-1305. Available: https://doi.org/10.1016/j.sjbs.2015.06.026

[129] Marles, R. J. and Farnsworth, N. R., 1995. "Antidiabetic plants and their active constituents." Phytomedicine, vol. 2, pp. 137-189. Available: https://doi.org/10.1016/S0944-7113(11)80059-0

[130] Ansari, P., Afroz, N., Jalil, S., Azad, S. B., Mustakim, M. G., Anwar, S., Haque, S. M. N., Hossain, S. M., Tony, R. R., et al., 2017. "Anti-hyperglycemic activity of Aegle marmelos (L.) corr. is partly mediated by increased insulin secretion, $\alpha$-amylase inhibition, and retardation of glucose absorption." J. Pediatr Endocrinol Metab, vol. 30, pp. 37-47. Available: https://doi.org/10.1515/jpem-2016-0160

[131] Palatty, P. L., Shivashankara, A. R., Baliga, M. S., Jaiswal, A., Pankaj, P., and Joseph, N., 2013. Chapter 41 - The Indian Medicinal Plant Aegle marmelos in the Treatment of Diabetes Mellitus: Promise and Prospects. In: Watson RR, Preedy VR (eds) Bioactive Food as Dietary Interventions for Diabetes. San Diego: Academic Press. pp. 519-536.

[132] Lin, X., Xu, Y., Pan, X., Xu, J., Ding, Y., Sun, X., Song, X., Ren, Y., and Shan, P. F., 2020. "Global, regional, and national burden and trend of diabetes in 195 countries and territories: an analysis from 1990 to 2025." Sci. Rep., vol. 10, p. 14790. Available: https://doi.org/10.1038/s41598-020-71908-9 